\title{
Identification of YdhV as first molybdoenzyme binding a bis-Mo-MPT cofactor in Escherichia coli
}

Stefan Reschke ${ }^{1 \dagger}$, Benjamin R. Duffus ${ }^{1 \dagger}$, Peer Schrapers ${ }^{2}$, Stefan Mebs ${ }^{2}$, Christian Teutloff ${ }^{3}$, Holger Dau ${ }^{2}$,Michael Haumann ${ }^{2 *}$, Silke Leimkühler ${ }^{*}$

${ }^{1}$ Institute of Biochemistry and Biology, University of Potsdam, Karl-Liebknecht-Str. 24, 14476 Potsdam, Germany

${ }^{2}$ Institute of Experimental Physics, Biophysics and Photosynthesis, Freie Universität Berlin, Arnimallee 14, 14195 Berlin, Germany

${ }^{3}$ Institute of Experimental Physics, EPR Spectroscopy of Biological Systems, Freie Universität Berlin, Arnimallee 14, 14195 Berlin, Germany

Author Contributions:

${ }^{\dagger}$ S.R and B.R.D. contributed equally to this work.

\section{*Corresponding Authors}

${ }^{1}$ Silke Leimkühler, Phone: +49 331977 5603, E-mail: sleim@uni-potsdam.de.

${ }^{2}$ Michael Haumann, Phone: +49 30838 56101, E-mail: michael.haumann@ fu-berlin.de. 


\begin{abstract}
The oxidoreductase $\mathrm{YdhV}$ in Escherichia coli has been predicted to belong to the family of molybdenum/tungsten cofactor (Moco/Wco) containing enzymes. In this study, we characterized the YdhV protein in detail, which shares amino acid sequence homologies to a tungsten-containing benzoyl-CoA reductase binding the bis-W-MPT (for metal-binding pterin) cofactor. Our studies showed that YdhV has a preference for molybdenum over tungsten as metal to be inserted into the MPT backbone. The cofactor was identified to be of a bis-MoMPT type, which represents a novel form of Moco that has not been found earlier in any molybdoenzyme. In-depth characterization of $\mathrm{YdhV}$ by X-ray absorption and EPR spectroscopy revealed that the bis-Mo-MPT cofactor in YdhV is redox active, while a bis-WMPT cofactor is redox inactive. The bis-Mo-MPT and bis-W-MPT cofactors include metal sites with the metal centers binding the four sulfurs from the two dithiolene groups in addition to a cysteine and likely a sulfido ligand. The unexpected presence of a bis-Mo-MPT cofactor opens an additional route for cofactor biosynthesis in E. coli and expands the canon of the structurally highly versatile molybdenum and tungsten cofactors.
\end{abstract}




\section{INTRODUCTION}

Molybdenum and tungsten are important trace elements that are essential in many biological systems. ${ }^{l}$ Both transition metals share comparable physicochemical properties that are utilized by numerous enzymes for catalytic reactions involving metal redox changes and group transfer reactions in concert with intramolecular electron and proton transfer.

The prototypical Mo or W cofactors include an unusual tricyclic pyranopterin moiety referred to as metal-binding pterin (MPT) ${ }^{2}$ After metal insertion, the MPT moiety is further modified, resulting in the diverse molybdenum (Moco) or tungsten (Wco) cofactor types. Moco or Wco containing enzymes are divided into three families according to the metal coordination environment in the cofactors as well as distinct active site structures and reaction types (Figure 1), namely the xanthine oxidase (XO), the sulfite oxidase ( $\mathrm{SO}$ ), and the dimethyl sulfoxide (DMSO) reductase families. ${ }^{3}$ The $\mathrm{XO}$ family is characterized by a $(\mathrm{MPT}) \mathrm{Mo} / \mathrm{W}\left(\mathrm{OSO}^{-}\right)$core in the oxidized state, with one MPT ligand bound to the metal. The sulfido-group (i.e. Mo=S) is cyanide labile. ${ }^{4}$ In enzymes of the XO family in prokaryotes, the cofactor can be modified by attachment of a CMP nucleotide to the phosphate group of Mo-MPT, forming the metalbinding-pterin cytosine dinucleotide (MCD) cofactor (Figure 1). ${ }^{5,6}$ 


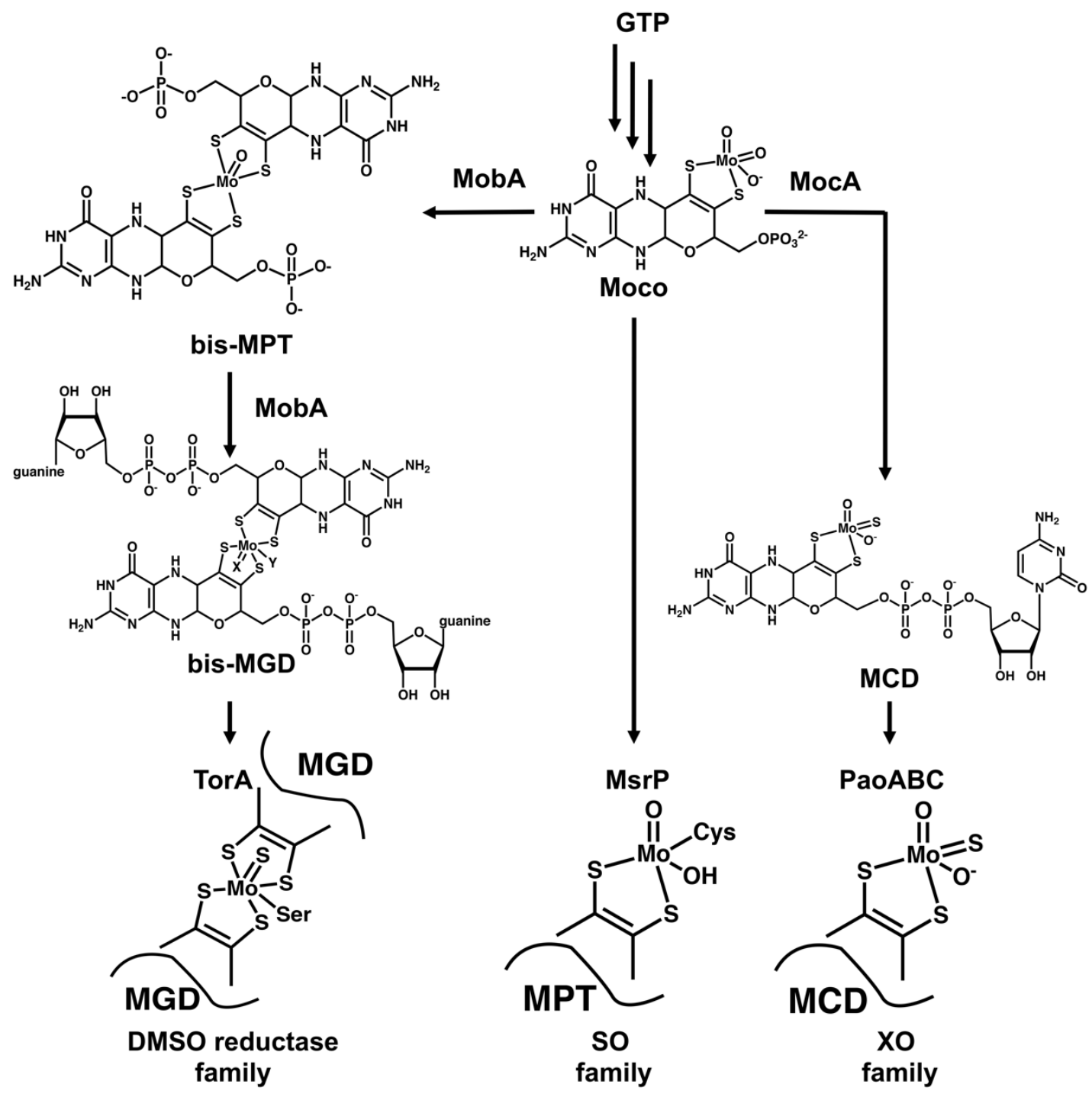

Figure 1: The three families of molybdoenzymes in $\boldsymbol{E}$. coli.

The metal-free form of the cofactor is denoted metal-binding pterin (MPT), a 5,6,7,8tetrahydropyranopterin. MPT is converted to Mo-MPT by insertion of the molybdenum atom. Mo-MPT (shown in the tri-oxo structure ${ }^{7}$ ) can be further modified and three different molybdenum-containing enzyme families are classified according to their coordination at the molybdenum atom: the $\mathrm{XO}, \mathrm{SO}$, and DMSO reductase families. The SO family is characterized by a MPT-Mo $\mathrm{Mo}^{\mathrm{VI}} \mathrm{O}_{2} \mathrm{Cys}$ ligand sphere and this cofactor is present in the E. coli MsrP protein. The XO family contains a MPT-Mo ${ }^{\mathrm{VI}} \mathrm{OS}(\mathrm{OH})$ core. Here, the MPT core can be modified by an additional CMP nucleotide at the phosphate group, forming MCD. The representative protein of this family in E. coli is the PaoABC protein. The DMSO reductase family contains a $\mathrm{MGD}_{2}-\mathrm{Mo}^{\mathrm{VI}} \mathrm{XY}$ core with $\mathrm{X}$ being either a sulfur or an oxygen ligand and $\mathrm{Y}$ either being a hydroxo or amino acid ligand (Ser, Cys, Sec, and Asp ligands have been identified thus far). The well-characterized representative of this family in E. coli is the TorA protein, that solely contains bis-MGD with a sulfido ligand and a serine ligand from the protein backbone.

CMP attachment to Mo-MPT is catalyzed by the MocA protein in Escherichia coli. ${ }^{8}$ Enzymes of the SO family show a (MPT)Mo( $\left(\mathrm{O}_{2}\right)$ core in the oxidized state and usually an additional 
cysteine ligand at the metal. The DMSO reductase family is exclusively present in bacteria and archaea and all members bind two pterin ligands at the metal in a $(\mathrm{MPT})_{2} \mathrm{Mo} / \mathrm{W}(\mathrm{XY})$ core. The ligand $\mathrm{X}$ can be a sulfido or oxo group. The $\mathrm{Y}$ ligand is typically an amino acid residue such as serine, cysteine, selenocysteine, or aspartate, but can be also a coordinated water species. In DMSO reductase family enzymes, further MPT modification occurs by addition of a GMP mononucleotide to the phosphate group, resulting in two MPT guanine dinucleotide (MGD) moieties at the bis-MGD cofactor. ${ }^{1,9-12}$ During bis-MGD synthesis, binding of two MPT molecules to one metal ion precedes addition of the GMP nucleotides. The step of bis-MPT formation and GMP addition is catalyzed by the MobA protein. For bis-MPT formation, metal ligation to MPT is obligatory ${ }^{13}$, but no further proteins are involved in the reaction. In the next step, a GMP molecule is added to each MPT bound to MobA and the resulting bis-MGD cofactor is inserted into the target enzymes by bis-MGD binding chaperones. ${ }^{7,14,15}$ Tungstencontaining enzymes grouped into the DMSO reductase family, like the aldehyde-ferredoxin oxidoreductase AOR from Pyrococcus furiosus or the benzoyl-CoA reductase BamBC from Geobacter metallireducens, ${ }^{16,17}$ were shown to bind a bis-W-MPT cofactor without guanine nucleotides attached to the terminal phosphate group of MPT. The synthesis of this cofactor is unexplored in these organisms.

In E. coli, numerous MPT-containing enzymes were identified, which all bind molybdenum at their active site. ${ }^{5,18} \mathrm{~A}$ well-characterized typical member of the $\mathrm{XO}$ family is the periplasmic aldehyde oxidoreductase PaoABC, binding the sulfido-containing $\mathrm{MCD}$ cofactor. ${ }^{5,18,19}$ The periplasmic methionine sulfoxide reductase (MsrP) is a typical member of the SO family that binds the Mo-MPT cofactor. ${ }^{5,20}$ However, the majority of molybdoenzymes in $E$. coli belong to the DMSO reductase family, binding the bis-MGD cofactor. ${ }^{3}$ Different ligands at the Mo-atom of members of this family were identified, including a recently characterized sulfido-ligand of E. coli TMAO reductase that is present at the Mo atom in 
addition to a serine ligand. ${ }^{21}$ This sulfido-ligand was first identified to be essential for the activity of formate dehydrogenases and periplasmic nitrate reductases that bind a proteinderived cysteine ligand instead. ${ }^{22,23}$ It has been suggested that the sulfido-group is sensitive to oxidative treatment, therefore this ligand might be present in more molybdoenzymes than originally expected. ${ }^{21}$

The so far uncharacterized proteins encoded by the $y d h Y V W X U T$ operon in E. $\operatorname{coli}^{24}$ were also grouped in the DMSO reductase family of molybdenum/tungsten enzymes. ${ }^{5}$ The $y d h Y V W X U T$ operon encoding a predicted oxidoreductase in E. coli was first described by Partridge et al. in 2008. ${ }^{24}$ These studies showed that the $y d h Y V W X U T$ genes are transcribed from an FNR-dependent promoter under anaerobic conditions. YdhV has been predicted to bind a MPT cofactor based on about $45 \%$ amino acid sequence homology to $P$. furiosus AOR and G. metallireducens BamBC. ${ }^{16,17,25}$ An YdhV mutant was reported to be impaired in anaerobic utilization of certain sulfur sources (e.g. L-cysteine, D-cysteine, L-cysteic acid, hypotaurine, butane sulphonic acid). ${ }^{24}$ No further characterization of this enzyme was available so far.

In this study, we characterized the purified cofactor-binding protein $\mathrm{YdhV}$ from E. coli in detail. The cofactor in the native enzyme was identified to be of the bis-Mo-MPT type and also the respective bis-W-MPT form can be assembled in the enzyme. bis-Mo-MPT represents a novel form of Moco that has not been observed in any molybdoenzyme before. The bisMo/W-MPT cofactors in YdhV likely contain a sulfido and a cysteine ligand at the metal. 


\section{MATERIALS AND METHODS}

\section{Bacterial strains, plasmids, media and growth conditions}

Escherichia coli BW25113 $\triangle m o b A$ and $\triangle m o c A$ cells were obtained from the Keio collection. ${ }^{26}$ The $\Delta m o b A / \Delta m o c A$ strain was constructed by introducing the mocA gene deletion into the $\triangle m o b A$ strain using P1 transduction. ${ }^{26}$ Successful deletion of $m o b A$ and $m o c A$ was checked by PCR amplification and enzyme activities of proteins expressed in these strains. For the expression of proteins, cells were generally grown, unless otherwise indicated, at $30{ }^{\circ} \mathrm{C}$ under aerobic conditions in LB medium containing $1 \mathrm{mM}$ molybdate, $20 \mu \mathrm{M}$ isopropyl $\beta$-D-1thiogalactopyranoside (IPTG) and $150 \mu \mathrm{g} / \mathrm{mL}$ ampicillin for $24 \mathrm{~h}$.

\section{Expression and purification of recombinant proteins}

The gene encoding $y d h V$ was amplified from the $E$. coli $\mathrm{K} 12$ genome. ${ }^{27}$ The published gene sequence was used to design primers that permitted cloning into the SacI and HindIII sites of the expression vector pTrcHis. ${ }^{28}$ The resulting plasmid, designated pSR153, contains the $y d h V$ gene with a His6-tag fused to the N-terminus of YdhV. For heterologous expression in E. coli, pSR153 was transformed into BW25113 cells. Additionally, two primer pairs were designed to clone the $y d h Y$ gene into the MCS-1 (multiple cloning side) and the $y d h W X U T$ genes into MCS-2 of pACYCDuet ${ }^{\mathrm{TM}}-1$ (Novagen), resulting in plasmid pSR242. The expression of $E$. coli TMAO reductase (TorA) from plasmid pJF119EH ${ }^{29}$, MsrP from plasmid $\mathrm{pSR}^{30}$ and PaoABC from plasmid $\mathrm{pMN} 11^{19}$ was performed according to the respective published procedures.

The E. coli K-12 strain BW25113 was employed for the expression of all proteins described herein, including those containing a deletion of the mobA, mocA and moaA genes. Expression pre-cultures were prepared in LB-medium containing $1 \mathrm{mM} \mathrm{Na}_{2} \mathrm{MoO}_{4}, 20 \mu \mathrm{M}$ IPTG and 150 $\mu \mathrm{g} / \mathrm{mL}$ ampicillin. Expression cultures were started with $2 \mathrm{~mL} / \mathrm{L}$ of an overnight culture and 
incubated at $30{ }^{\circ} \mathrm{C}$ and $130 \mathrm{rpm}$ for $24 \mathrm{~h}$. YdhV additionally was expressed with different $\mathrm{Na}_{2} \mathrm{WO}_{4}{ }^{2-}(0-100 \mu \mathrm{M})$ or $\mathrm{Na}_{2} \mathrm{MoO}_{4}{ }^{2-}$ concentrations $(0-100 \mu \mathrm{M})$ in presence of either 10 $\mu \mathrm{M} \mathrm{Na} \mathrm{MoO}_{4}{ }^{2-}$ or $10 \mu \mathrm{M} \mathrm{Na} \mathrm{WO}_{4}{ }^{2-}$, respectively. Anaerobic expression of $\mathrm{YdhV}$ was performed similarly to aerobic expression, only in that the cultures incubated statically in closed flasks at $30^{\circ} \mathrm{C}$ for $24 \mathrm{~h}$.

Purification was performed either aerobically at $4{ }^{\circ} \mathrm{C}$ or anaerobically in a Coy chamber $\left(\mathrm{O}_{2}<\right.$ $10 \mathrm{ppm})$. The cells were harvested by centrifugation and the cell pellets were resuspended in phosphate buffer $\left(50 \mathrm{mM} \mathrm{NaH}_{2} \mathrm{PO}_{4}, 300 \mathrm{mM} \mathrm{NaCl}, \mathrm{pH}\right.$ 8.0). $20 \mathrm{~mL}$ of cell pellet were lysed by sonification in a $50 \mathrm{~mL}$ Falcon tube for $6 \mathrm{~min}$ in an icebath. The cleared lysate was applied to $0.7 \mathrm{~mL}$ nickel-nitrilotriacetate (Ni-NTA) resin per liter of culture. The column was washed with 20 column volumes of phosphate buffer each, first with one containing $10 \mathrm{mM}$ imidazole and then with one containing $20 \mathrm{mM}$ imidazole. Proteins were eluted with phosphate buffer containing $250 \mathrm{mM}$ imidazole. Subsequently buffer exchange was performed by using Sephadex G25 desalting columns with the following protein-specific buffers: MsrP, $50 \mathrm{mM}$ $\mathrm{NaH}_{2} \mathrm{PO}_{4}, 300 \mathrm{mM} \mathrm{NaCl}, \mathrm{pH}$ 8.0; PaoABC, 50 mM Tris-HCl, pH 7.5; YdhV and TorA, 100 $\mathrm{mM}$ Tris-HCl, $\mathrm{pH} 7.2$.

YdhV samples for X-ray absorption spectroscopy were prepared in a similar fashion as described above. Mo-containing YdhV was expressed aerobically, whereas W-containing YdhV was expressed anaerobically. Slight modifications to the expression and purification procedures were applied. Briefly, expression cultures were supplemented with either $\mathrm{MoO}_{4}{ }^{2-}$ or $\mathrm{WO}_{4}{ }^{2-}$ concentrations of $1 \mathrm{mM}$ or $10 \mu \mathrm{M}$ and $1 \mathrm{mM}$, respectively. YdhV was purified as described above, however for $\mathrm{Br}^{-}$containing samples, the $300 \mathrm{mM} \mathrm{NaCl}$ present in the imidazole buffers was replaced by $300 \mathrm{mM} \mathrm{NaBr}$, and samples underwent buffer exchange into $100 \mathrm{mM}$ Tris-HBr, $\mathrm{pH}$ 7.2. For chloride-free samples, YdhV purified with chloride underwent buffer exchange into $100 \mathrm{mM}$ Tris-acetate, $\mathrm{pH} 7.2$. 


\section{Activity assays}

The activity of PaoABC was determined spectrophotometrically by monitoring the reduction of $1 \mathrm{mM}$ ferricyanide at $420 \mathrm{~nm}$ using a UV-visible spectrophotometer in a $1 \mathrm{~mL}$ cuvette as described previously. ${ }^{19}$ The substrate vanillin was used in $100 \mathrm{mM}$ Tris $\mathrm{pH} 6.8$ with protein concentration of 5-20 $\mu \mathrm{M}$.

The activity of TorA and MsrP using an enzyme concentration of 5-20 $\mu \mathrm{M}$ was measured in 1 $\mathrm{mL}$ cuvettes at $600 \mathrm{~nm}$ containing $4 \mu \mathrm{L}$ of $100 \mathrm{mM}$ benzyl viologen, $5 \mu \mathrm{L}$ of $1.5 \mathrm{M}$ TMAO, and sodium dithionite as described previously. ${ }^{29-31}$ The activity of TorA was measured in 100 $\mathrm{mM} \mathrm{KH} \mathrm{PO}_{4}(\mathrm{pH} 6.5)$ and the activity of MsrP was measured in citrate phosphate buffer $(\mathrm{pH}$ $5)$.

To attempt identification of the substrate of $\mathrm{YdhV}$, several substrates under different conditions were tested, i.e. in the context of the broad scope of reactions that so far characterized molybdoenzymes are able to perform. Briefly, the oxidation and reduction of formaldehyde, acetaldehyde, crotonaldehyde, butyraldehyde, hexanal, glyceraldehyde, benzaldehyde, glutaraldehyde and benzoyl-CoA in the presence of benzyl viologen and/or methyl viologen was tested at $\mathrm{pH}$ 5.0, 7.2 and 9.0. YdhV electron acceptor/donor activity was assessed using ferricyanide/ferrocyanide, methylene blue and DCPIP. In addition, redox reactions coupled to methyl viologen regeneration, as described above for TorA and MsrP, were adapted to YdhV with the following potential substrates: cystine, cysteine, methionine sulfoxide, sulfate, methionine, sodium dithionite, dithiothreitol (DTT), $\mathrm{Na}_{2} \mathrm{~S}$, DMSO, TMAO, xanthine, vanillin, sodium nitrate, sodium chlorate, sodium perchlorate, $\mathrm{O}_{2}$, sodium molybdate, $\mathrm{FeCl}_{3}$, glucose and sucrose.

We further tried activity assays of YdhV co-expressed with the $y d h Y W X U T$ operon after aerobic or anaerobic expression. Redox cycling or the anaerobic reconstitution of the Fe-S cluster in $\mathrm{YdhV}$ were carried out in addition. 


\section{Quantification of metal and Moco saturations}

Metal contents of proteins were determined for protein concentrations of about 10-1000 $\mu \mathrm{M}$. The quantifications of Mo, W, Fe, or P were performed using inductively coupled plasma optical emission spectroscopy (ICP-OES) on a PerkinElmer Life Sciences Optima 2100DV instrument or total reflection X-ray fluorescence (TXRF) analysis on a PicoFox spectrometer (Bruker) as described previously. ${ }^{32,33}$

MPT contents were determined fluorometrically after conversion of the molecule to FormA, as described previously. ${ }^{34}$ While an incubation for $30 \mathrm{~min}$ at $95^{\circ} \mathrm{C}$ in the presence of acidic iodine oxidizes all released Moco derivates to the fluorescent FormA, an overnight incubation at room temperature results in FormA-NMP derivates with the nucleotide retained. $0.5-30 \mu \mathrm{M}$ of proteins were used for the oxidation by acidic $\mathrm{I}_{2} / \mathrm{KI}$. FormA and Form-A-GMP or FormACMP were separated by a C18 reversed-phase high pressure liquid chromatography column (4.6 x $250 \mathrm{~mm}$ Hypersil ODS, $5 \mu \mathrm{m}$ particle size) according to the method described previously. ${ }^{34}$ The fluorescence of FormA, FormA-CMP and FormA-GMP was quantified by an Agilent 1260-series detector using excitation at $383 \mathrm{~nm}$ and emission detection at $450 \mathrm{~nm}$.

\section{ICP-MS}

Aliquots of $100 \mu \mathrm{L}$ of $16.4 \mu \mathrm{M}$ YdhV were digested using $1 \mathrm{~mL} \mathrm{HNO}_{3}$ and $900 \mu \mathrm{L}$ of $\mathrm{H}_{2} \mathrm{O}$ (containing $5 \mu \mathrm{g} / \mathrm{L} \mathrm{Rh}$ as internal standard) in a MARS 6 closed vessel microwave system (CEM) at $200{ }^{\circ} \mathrm{C}$ for $20 \mathrm{~min}$. The digestion solution was transferred to a sample vial and diluted 1:10 at least. Blank digestions were processed in the same way.

The concentrations of Mo and P were simultaneously quantified by ICP-MS (Agilent 8800 ICP-QQQ) in the MS/MS mode using oxygen as reaction gas. The nebulizer gas flow and parameters of lenses, Q1, collision cell and Q2 were tuned daily for maximum sensitivity 
(oxide ratio $<1.0 \%(140 \mathrm{Ce} 16 \mathrm{O}+/ 140 \mathrm{Ce}+)$, double charged ratio $<1.5 \%(140 \mathrm{Ce}++/ 140 \mathrm{Ce}+)$, background counts $<0.1 \mathrm{cps})$. For quantification an element mix $(100 \mathrm{mg} / \mathrm{L}$, Merck $-\mathrm{XVI})$ was diluted in $5 \% \mathrm{HNO}_{3}$ as an external calibration standard.

\section{X-ray absorption spectroscopy}

Protein samples for XAS were prepared by concentrating YdhV (Merck Amicon Ultra-0.5 Centrifugal Filter Units, $10 \mathrm{kDa}$ cutoff $)$ in the absence $\left(\mathrm{YdhV}^{\mathrm{ox}}\right)$ or presence $\left(\mathrm{YdhV}^{\mathrm{red}}\right)$ of a 10fold excess of sodium dithionite, resulting in $\mathrm{YdhV}$ in the as-isolated (oxidized) or reduced states, respectively. Samples were loaded into acrylic-glass sample holders (50 $\mu \mathrm{L})$, sealed with Kapton tape, and were flash-frozen and stored in liquid nitrogen until use. To follow redox changes of $\mathrm{YdhV}$, the prepared XAS samples were subjected to additional treatments at the beamline. Following XAS (Mo) data collection for $\mathrm{YdhV}^{\text {red }}$, the sample was thawed and exposed to air for $10 \mathrm{~min}$ reoxidiation before freezing again in liquid nitrogen $\left(\mathrm{YdhV}^{\mathrm{reox}}\right)$. Likewise, following XAS (Mo) data collection for $\mathrm{YdhV}^{\text {reox }}$, the sample was thawed and incubated with a 10-fold excess of sodium dithionite for 10 min reduction before freezing again $\left(\mathrm{YdhV}^{\text {rered }}\right)$.

Mo K-edge ${ }^{35}$ XAS was carried out at the Samba beamline at Soleil synchrotron (Paris, France) using a standard set-up (double-crystal Si[220] monochromator, 36 element energy-resolving Ge detector for fluorescence data collection) as previously described. ${ }^{7,}{ }^{35}, 36$ Fe K-edge and W $\mathrm{L}_{3}$-edge XAS was carried out at beamline KMC-3 at BESSY-II (Helmholtz Center Berlin, Germany) using a standard set-up (double-crystal Si[111] monochromator, 13-element energyresolving Ge detector). Samples were held in a liquid-helium cryostat at $20 \mathrm{~K}$. The monochromator energy axes were calibrated using Mo, Fe, or W metal foils (reference energies: Mo, $20003.9 \mathrm{eV}$; Fe, $7112.0 \mathrm{eV}$; W, $10206.8 \mathrm{eV})$. Up to 10 XAS scans ( 30 min duration, one scan per sample spot) were averaged for signal-to-noise ratio improvement. 
XANES and EXAFS spectra were derived as described earlier. ${ }^{33,35-37}$ EXAFS simulations were performed with in-house software ${ }^{37}$ and phase functions calculated by FEFF9 $\left(\mathrm{S}_{0}^{2}=1.0\right.$, Mo and $\mathrm{W}$, or $0.85, \mathrm{Fe}) .{ }^{38}$ EXAFS Fourier transforms (FTs) were calculated for $k$-ranges of 1.6$14.0 \AA^{-1}$ (Mo and $\left.\mathrm{W}\right)$ or 1.6-12.0 ̊ (Fe) (10\% cos windows).

\section{EPR spectroscopy}

EPR samples were prepared either aerobically in an ice bath or anaerobically in a Coy Chamber at $\mathrm{O}_{2}$ levels $<10 \mathrm{ppm}$ at $4{ }^{\circ} \mathrm{C}$ in a thermoblock, in $100 \mathrm{mM}$ Tris- $\mathrm{HCl}, \mathrm{pH}$ 7.2. Typical EPR sample preparation methods involved addition of $20 \mu \mathrm{L}$ of freshly-prepared sodium dithionite or potassium ferricyanide (10 mM final concentration) to $180 \mu \mathrm{L}$ of as-isolated YdhV residing in a quartz EPR capillary (3.9 mm O.D.), followed by brief mixing and immediate freezing (510 seconds aerobically, $15-20$ seconds anaerobically) in a liquid $\mathrm{N}_{2}$-cooled ethanol bath before final freezing in liquid $\mathrm{N}_{2}$. Anaerobic samples were additionally gas-tight sealed prior to freezing outside of the chamber. EPR sample anaerobicity is noted in Table S1.

CW X-band EPR spectra were obtained using a laboratory-built spectrometer (microwave bridge, ER041MR, Bruker; lock-in amplifier, SR810, Stanford Research Systems; microwave counter, 53181A, Agilent Technologies) equipped with a Bruker SHQ resonator. An ESR 910 helium flow cryostat with an ITC503 temperature controller (Oxford Instruments) was used for temperature control. A $\mathrm{Cu}(\mathrm{II}) / \mathrm{EDTA}$ standard was used as a reference for spin quantitation of YdhV samples. Spin quantitation was performed using the utility 'spincounting' (http://lcts.github.io/spincounting/) in Matlab (Mathworks). Spectral simulations were performed using EasySpin in Matlab. ${ }^{39}$ Field corrections were applied as needed through measuring a reference $\mathrm{N} @ \mathrm{C}_{60}$ sample at ambient temperature to give the expected spin Hamiltonian parameters as reported elsewhere..$^{40}$ Typical parameters for EPR data acquisition were (unless otherwise noted): temperature, $80 \mathrm{~K}$; modulation amplitude, $5 \mathrm{G}$; microwave 
power, $4.0 \mathrm{~mW}$; microwave frequency, $9.38 \mathrm{GHz}$. Microwave power saturation data were fitted as a double logarithmic plot using OriginPro (version 9.1.0) to the equation:

$$
S=K \frac{\sqrt{P}}{\left(1+\frac{P}{P_{1 / 2}}\right)^{0.5 b}}
$$

where $S$ is the signal intensity, $K$ is a proportionality constant, $P$ is the microwave power, $P_{1 / 2}$ is the microwave power at half-saturation, and $b$ is the inhomogeneity parameter. ${ }^{41}$

\section{RESULTS}

\section{YdhV protein expression and purification}

For characterization of the $\mathrm{YdhV}$ protein, a homologous expression system was established in E. coli. For separate YdhV expression, the coding sequence was amplified from E. coli K12 total DNA and cloned into the vector pTrcHis, which results in an N-terminal fusion of the protein with a His6-tag. Additionally, the other genes of the operon were cloned into the pACYC-duet1 vector, $y d h Y$ into MCS1 and $y d h W X U T$ into MCS2, which enabled coexpression with YdhV. Both vectors or vector pTrcHis-YdhV alone were transformed into BW25113 cells and expressed as described in Materials and Methods. In both cases, Ni-NTA chromatography yielded only the $\mathrm{YdhV}$ protein and no further proteins (data not shown), so that for all further characterizations the pTrcHis-YdhV construct was used for protein expression. $\mathrm{YdhV}$ was expressed with a yield of $17 \mathrm{mg}$ protein per liter of E. coli culture and was purified by Ni-NTA chromatography and size exclusion chromatography, resulting in a monomeric protein with a molecular mass closely resembling the calculated value of $77.8 \mathrm{kDa}$ (Figures 2A and B). The optical absorption spectrum shows the characteristic features for an enzyme containing a molybdenum cofactor ${ }^{42}$, which was reducible by the addition of sodium dithionite (Figure 2C). Characteristic features corresponding to the [4Fe-4S] cluster predicted to be bound to the protein were not clearly discernable in the absorption spectrum (Figure 2C). 
Unfortunately, so far we were unable to establish an activity assay for $\mathrm{YdhV}$, since no activity could be detected with any of the numerous substrates that were tested (see Materials and Methods for details).
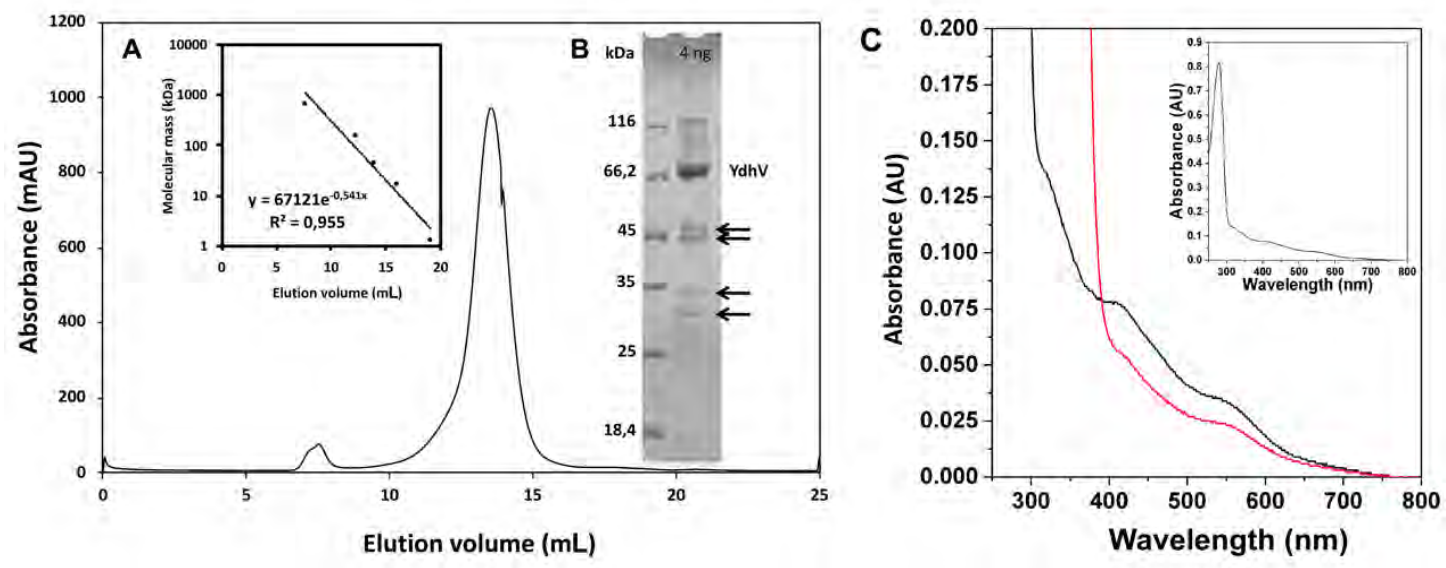

Figure 2: Purification of YdhV

(A) Size exclusion chromatography of $\mathrm{YdhV}$. YdhV was analyzed by analytical size exclusion chromatography in $100 \mathrm{mM}$ Tris and $200 \mathrm{mM} \mathrm{NaCl}$ (pH 7.2) using a Superdex 200 column. Inset: Relation of molecular weight and elution volume for standard proteins. Size exclusion chromatography markers (Bio-Rad): c-globulin (158 kDa), ovalbumin (44 kDa), myoglobin (17 kDa), and vitamin B12 (1.3 kDa). (B) 10\% SDS polyacrylamide gel of YdhV after NiNTA chromatography. The bands marked by arrows were assigned to degradation products of YdhV by MALDI-TOF mass spectrometry. (C) UV-visible absorption spectra of $6.5 \mu \mathrm{M}$ YdhV in $100 \mathrm{mM}$ Tris/ $\mathrm{HCl}$ pH 7.2 (as-purified YdhV, black line, and reduced YdhV with 10-fold excess of sodium dithionite, red line.) The inset shows the overall spectrum of the as-purified protein.

\section{Identification of the type of Moco present in YdhV}

To analyze the type of Moco present in YdhV, we expressed the enzyme in different $E$. coli mutant strains. So far, only molybdoenzymes have been identified in E. coli and tungstencontaining enzymes were not expected to be produced. YdhV was expressed in the presence of $1 \mathrm{mM}$ molybdate and the molybdenum and iron contents in the enzyme were determined. To identify whether YdhV binds a bis-MGD cofactor with additional guanine nucleotides as present in TMAO reductase (TorA), a MCD cofactor with a cytosine nucleotide as in PaoABC, or a Mo-MPT cofactor identified in MsrP, we quantified the metal, Moco and nucleotide content (as FormA-NMP) of $\mathrm{YdhV}$ in comparison to the mentioned enzymes serving as 
controls (Table 1). The proteins were expressed in the BW25113 wild-type E. coli strain, $\triangle m o b A$ and $\triangle m o c A$ deletion strains impaired in bis-MGD or MCD biosynthesis, and in a $\triangle m o b A / \triangle m o c A$ double-deletion strain, respectively.

Table 1: Relative activity and metal/Moco loading of TorA, PaoABC, MsrP and YdhV.

\begin{tabular}{lccccc} 
TorA $^{\mathbf{a}}$ & Mo $^{\mathbf{b}}$ & Fe $^{\mathbf{b}}$ & FormA $^{\mathbf{c}}$ & $\begin{array}{c}\text { FormA- } \\
\text { NMP }^{\mathbf{c}}\end{array}$ & $\begin{array}{c}\text { Relative } \\
\text { activity }^{\mathbf{d}}\end{array}$ \\
\hline BW25113 & $1.00 \pm 0.03$ & n.d. & $1.00 \pm 0.11$ & $1.00 \pm 0.07$ & $1.00 \pm 0.04$ \\
$\Delta$ mobA & $0.60 \pm 0.04$ & n.d. & $0.08 \pm 0.01$ & n.d. & n.d. \\
$\Delta$ mocA & $1.05 \pm 0.02$ & n.d. & $1.06 \pm 0.08$ & $1.00 \pm 0.21$ & $1.18 \pm 0.06$ \\
\hline mobA $\Delta$ mocA & $0.65 \pm 0.03$ & n.d. & $0.07 \pm 0.01$ & n.d. & n.d. \\
\hline
\end{tabular}

\begin{tabular}{|c|c|c|c|c|c|}
\hline PaoABCa & $\mathbf{M o}^{b}$ & $\mathbf{F e}^{\mathbf{b}}$ & FormA ${ }^{c}$ & $\begin{array}{c}\text { FormA- } \\
\text { NMPc }\end{array}$ & $\begin{array}{l}\text { Relative } \\
\text { activity }\end{array}$ \\
\hline BW25113 & $1.00 \pm 0.03$ & $1.00 \pm 0.06$ & $1.00 \pm 0.07$ & $1.00 \pm 0.26$ & $1.00 \pm 0.07$ \\
\hline$\triangle \mathrm{mobA}$ & $0.55 \pm 0.04$ & $0.99 \pm 0.04$ & $0.56 \pm 0.17$ & $0.35 \pm 0.16$ & $0.47 \pm 0.12$ \\
\hline$\triangle \mathrm{mocA}$ & $0.33 \pm 0.04$ & $1.01 \pm 0.04$ & $0.40 \pm 0.20$ & n.d. & n.d. \\
\hline$\triangle \mathrm{mobA} \triangle \mathrm{mocA}$ & $0.42 \pm 0.03$ & $0.97 \pm 0.03$ & $0.27 \pm 0.16$ & n.d. & n.d. \\
\hline
\end{tabular}

\begin{tabular}{lccccc} 
MsrPa & Mo $^{\mathbf{b}}$ & Fe $^{\mathbf{b}}$ & FormA $^{\mathbf{c}}$ & $\begin{array}{c}\text { FormA- } \\
\text { NMPc }^{\mathbf{c}}\end{array}$ & $\begin{array}{c}\text { Relative } \\
\text { activity }^{\mathbf{d}}\end{array}$ \\
\hline BW25113 & $1.00 \pm 0.02$ & n.d. & $1.00 \pm 0.13$ & n.d. & $1.00 \pm 0.07$ \\
$\Delta$ mobA & $0.87 \pm 0.03$ & n.d. & $1.02 \pm 0.07$ & n.d. & $0.88 \pm 0.04$ \\
$\Delta$ mocA & $0.91 \pm 0.02$ & n.d. & $0.91 \pm 0.13$ & n.d. & $1.19 \pm 0.05$ \\
$\Delta$ mobA $\triangle$ mocA & $0.98 \pm 0.01$ & n.d. & $1.51 \pm 0.01$ & n.d. & $1.34 \pm 0.07$ \\
\hline
\end{tabular}

\begin{tabular}{lccccc} 
YdhV $^{\mathbf{a}}$ & Mo $^{\mathbf{b}}$ & Fe $^{\mathbf{b}}$ & FormA $^{\mathbf{c}}$ & $\begin{array}{c}\text { FormA- } \\
\text { NMP }^{\mathbf{c}}\end{array}$ & $\begin{array}{c}\text { Relative } \\
\text { activity }^{\mathbf{d}}\end{array}$ \\
\hline BW25113 & $1.00 \pm 0.02$ & $1.00 \pm 0.03$ & $1.00 \pm 0.09$ & n.d. & n.d. \\
$\Delta$ mobA & $0.71 \pm 0.15$ & $0.85 \pm 0.04$ & $2.23 \pm 0.27$ & n.d. & n.d. \\
\hline mocA & $0.75 \pm 0.02$ & $0.88 \pm 0.04$ & $0.84 \pm 0.07$ & n.d. & n.d. \\
\hline mobA $\triangle$ mocA & $0.63 \pm 0.02$ & $0.84 \pm 0.03$ & $2.12 \pm 0.23$ & n.d. & n.d. \\
\hline
\end{tabular}

${ }^{a}$ The enzymes were expressed in E. coli BW25113 and $\triangle m o b A, \triangle m o c A$ or $\triangle m o b A / m o c A$ deletion strains for comparison.

${ }^{\mathrm{b}}$ Metal contents (metal/enzyme) were determined by ICP-OES and normalized to the values for enzymes purified from the BW25113 wild-type strain set to 1 .

${ }^{\mathrm{c}}$ The Moco content of the enzymes was quantified after conversion of MPT or MPT-NMP to FormA or FormA-NMP and normalized to the values for enzymes purified from the BW25113 wild-type strain set to 1 .

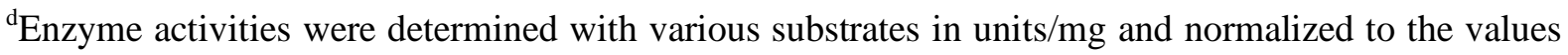
for enzymes purified from the BW25113 wild-type strain set to 1 .

n.d. = not detectable.

Data represent the mean values from at least three independent measurements ( \pm standard deviations).

The controls showed the expected behavior, with TorA being inactive in the $\triangle m o b A$ and $\triangle m o b A / \triangle m o c A$ strains impaired in bis-MGD synthesis (no FormA or FormA-GMP detectable), 
while a mocA deletion had no effect on TorA. PaoABC was inactive in the $\triangle m o c A$ and $\Delta m o b A \Delta m o c A$ strains (no FormA-CMP detectable). For MsrP no impairment in activity was detected in all mutant strains and the data were comparable to wild-type levels. For YdhV, we also did not detect the presence of FormA-NMP in any of the analysed strains. The molybdenum and iron contents of YdhV expressed in the deletion strains were $80-100 \%$ of the wild-type strain. While the FormA levels in the $\Delta m o c A$ strain were comparable to the wildtype strain, an up to two-fold higher FormA content was detected in $\triangle m o b A$ and $\triangle m o b A / \triangle m o c A$ mutant strains. This shows that the Moco, which is assembled and inserted in YdhV, does not depend on the activity of MobA or MocA. The absence of FormA-NMP indicates that likely no nucleotide is attached to the Moco of YdhV and consequently a Mo-MPT cofactor has to be bound to the enzyme.

After identification of a nucleotide-free Moco form in YdhV, we studied whether MoMPT, as present in MsrP, or a bis-MPT cofactor form containing two MPT moieties, as present in the homologous tungsten-containing enzymes $\mathrm{AOR}$ and BamBC, is bound to YdhV. In the past, we have identified a bis-Mo-MPT cofactor in MobA, e.g., by determination of the molybdenum to phosphorous ratio in the protein. The expected P:Mo ratios for the bis-MPT and MPT cofactors are 2:1 and 1:1, respectively. ${ }^{7}$ For comparison, here we applied two different methods to determine the P:Mo ratio in YdhV (Table 2). Quantification by ICP-MS revealed a P:Mo ratio close to 2:1. This ratio was confirmed by $\mathrm{P}$ quantification using TXRF (Table S2) in relation to the Mo content from ICP-OES, which gave a ratio of about 2.2:1. Based on these results a bis-Mo-MPT cofactor is most likely present in YdhV.

Table 2: Phosphorus to molybdenum ratio in YdhV.

\begin{tabular}{cc} 
Sample & P [per protein] : Mo [per protein] \\
\hline YdhV $^{\mathrm{a}}$ & $\mathbf{2 . 0 7}( \pm 0.58)^{\mathrm{b}}: \mathbf{1}( \pm 0.03)^{\mathrm{b}}$ \\
$\mathrm{YdhV}^{\mathrm{a}}$ & $\mathbf{2 . 1 7}( \pm 0.22)^{\mathrm{c}}: \mathbf{1}( \pm 0.07)^{\mathrm{d}}$ \\
\hline
\end{tabular}


${ }^{\mathrm{a}} 1.64 \mu \mathrm{M}$ YdhV was used for ICP-MS and $3.175 \mathrm{mM}$ YdhV for TXRF and $50 \mu \mathrm{M}$ YdhV for ICP-OES analyses. The molybdenum saturation in the proteins was normalized to 1 .

${ }^{\mathrm{b}} \mathrm{Mo}$ and $\mathrm{P}$ were determined by ICP-MS

${ }^{\mathrm{c}} \mathrm{P}$ contents were determined by TXRF (Table S2). ${ }^{7}$

${ }^{\mathrm{d}}$ Mo was quantified by ICP-OES. ${ }^{7}$

\section{Specificity of YdhV towards molybdenum or tungsten}

Since a bis- MPT cofactor was so far identified only in enzymes that contain a tungsten ion, the ability of YdhV in E. coli to bind tungsten versus molybdenum was assessed. Competitive Mo vs. W binding to YdhV was studied by expression of $\mathrm{YdhV}$ in the presence of $10 \mu \mathrm{M}$ molybdate and increasing tungstate concentrations or vice versa. After purification of $\mathrm{YdhV}$, the Mo and $\mathrm{W}$ contents in the enzyme were quantified (Figure 3). With $10 \mu \mathrm{M}$ molybdate, YdhV showed $20 \%$ Mo loading. The molybdenum saturation of YdhV increased up to $65 \%$ when $100 \mu \mathrm{M}$ tungstate were additionally present in the medium during expression, likely based on a better uptake of molybdate into the cells (Figure 3A). In contrast, the tungsten loading was rather small $(\sim 10 \%)$ after expression with $10 \mu \mathrm{M}$ molybdate and $100 \mu \mathrm{M}$ tungstate, whereas with $10 \mu \mathrm{M}$ tungstate in the absence of molybdate, the tungsten levels reached $20 \%$ (Figure 3B). However, with increasing molybdate concentrations during expression, the tungsten content decreased, meaning that $\mathrm{W}$ binding to the enzyme was outcompeted by Mo binding due to an apparently higher specificity for Mo insertion (Figure 3B). These findings show that when Mo is available even at low concentrations, the bis-MoMPT cofactor is preferentially inserted into $\mathrm{YdhV}$. 

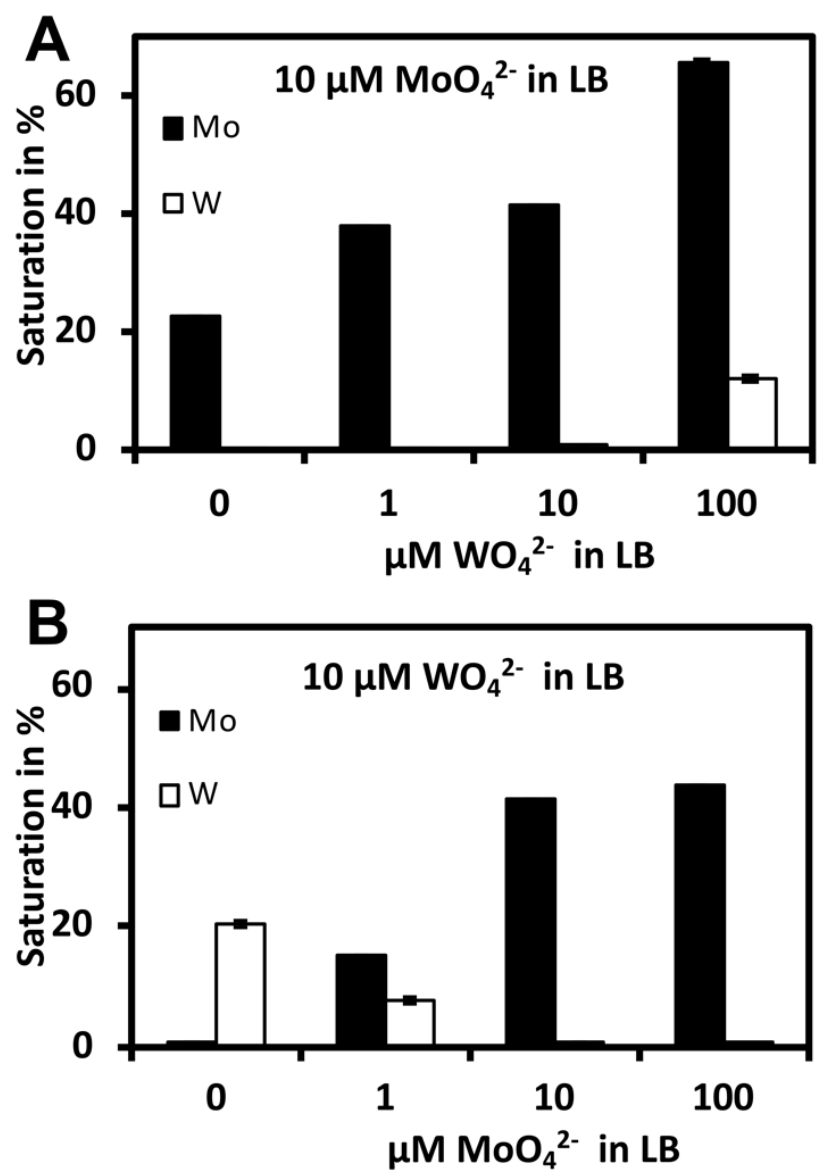

Figure 3: Competition of molybdenum versus tungsten insertion into YdhV. Expression of YdhV in the presence of $10 \mu \mathrm{M}$ Mo in LB with increasing W concentrations (A). Expression of $\mathrm{YdhV}$ in the presence of $10 \mu \mathrm{M} \mathrm{W}$ in LB with increasing Mo concentrations (B).

\section{Mo site structure in YdhV from XAS}

XAS was employed to characterize the metal site structure in YdhV expressed with molybdenum. Figure 4 shows XAS spectra at the Mo K-edge. We compared the as-isolated (oxidized) enzyme purified under aerobic conditions $\left(\mathrm{YdhV}^{\mathrm{ox}}\right)$ to the dithionite-reduced enzyme (YdhV red $)$. The XANES of $\mathrm{YdhV}^{\mathrm{ox}}$ showed a resolved pre-edge feature due to resonant $1 \mathrm{~s} \rightarrow 4 \mathrm{~d}$ electron excitation, which almost disappeared in $\mathrm{YdhV}^{\mathrm{red}}$ (Figure 4A). In addition, $\mathrm{YdhV}^{\text {ox }}$ showed a considerably higher K-edge energy ( $\sim 0.5 \mathrm{eV}$ at edge half-height), which indicates significantly more oxidized Mo compared to $\mathrm{YdhV}^{\text {red }}$. The K-edge energy of $\mathrm{YdhV}^{\text {ox }}$ $(\sim 20012.8 \mathrm{eV})$ and the relatively small pre-edge feature are in good agreement with predominantly sulfur-coordinated $\mathrm{Mo}(\mathrm{VI}){ }^{7}, 30,36$ The edge energy downshift due to Mo 
reduction presumably is superimposed by a counter-directed edge shift due to coordination changes at Mo, as indicated by the pre- and main-edge shape changes and the EXAFS analysis below, meaning that the metal was reduced at least to the $\mathrm{Mo}(\mathrm{V})$ if not to the $\mathrm{Mo}(\mathrm{VI})$ level in $\mathrm{YdhV}^{\text {red }}$. Redox cycling of YdhV (air re-oxidation of $\mathrm{YdhV}^{\text {red }}$ leading to $\mathrm{YdhV}^{\text {reox }}$ and NaDT re-reduction of $Y d h V^{\text {reox }}$, leading to $\mathrm{YdhV}^{\text {rered }}$ ) caused respective increase and decrease of the pre-edge feature and similar K-edge energy changes in $\mathrm{YdhV}^{\text {reox }}$ or $Y \mathrm{dh}^{\text {rered }}$, emphasizing the reversibility of the redox events at the Mo center. 


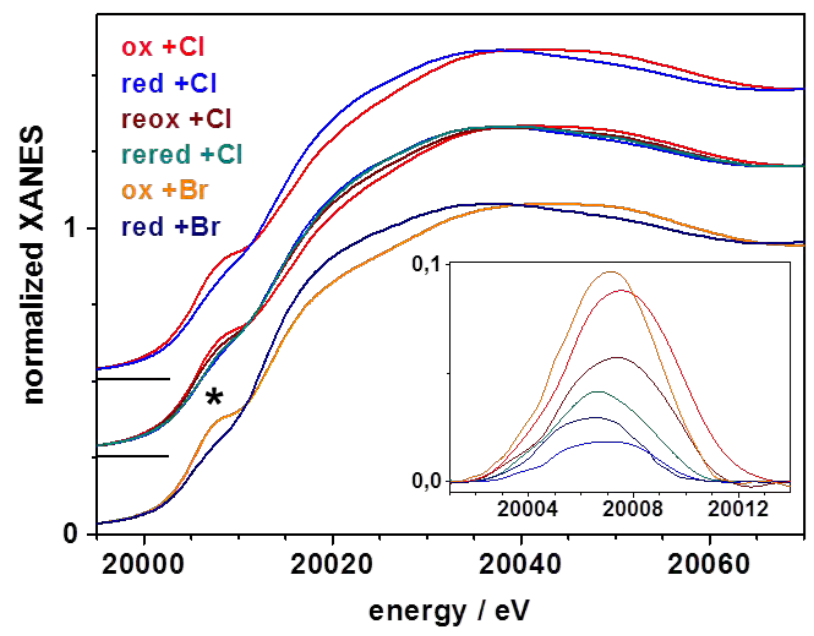

A

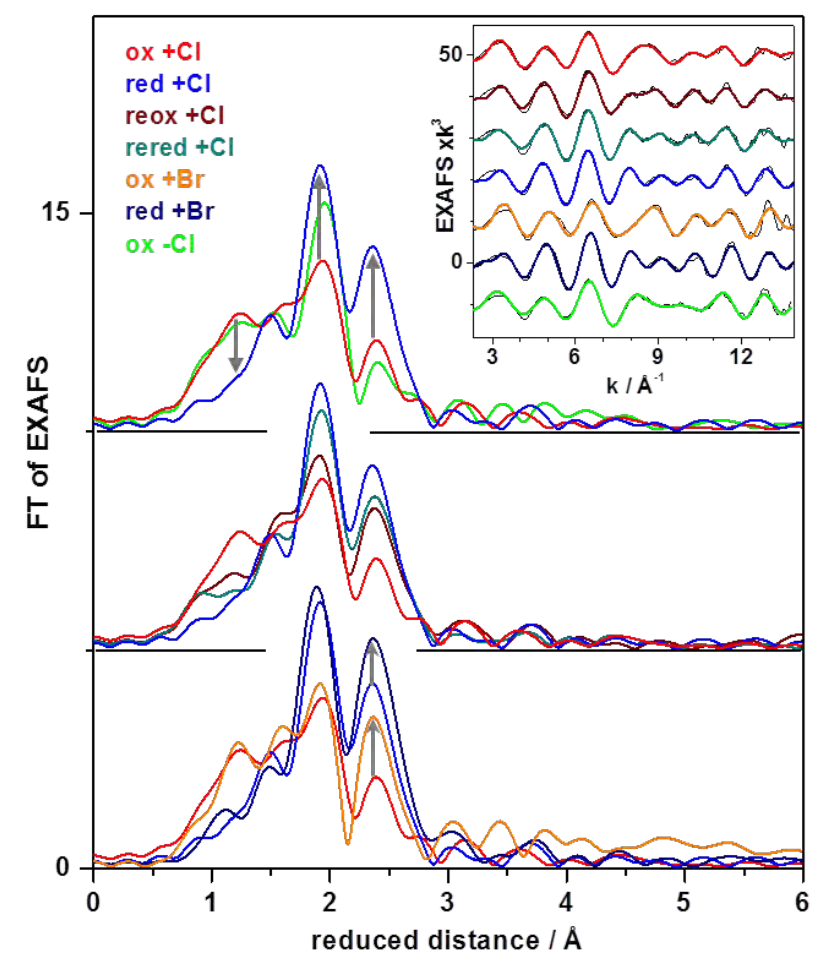

B

Figure 4: XAS analysis of YdhV. (A) Mo K-edge spectra (XANES) of (top) as-isolated, oxidized (ox) or sodium-dithionite reduced (red) enzyme in $\mathrm{Cl}^{-}$-containing buffer, (middle) of the latter enzyme samples as well as of enzyme after re-oxidation (reox) followed by rereduction (rered) in $\mathrm{Cl}^{-}$-containing buffer, and (bottom) of oxidized or reduced enzyme in $\mathrm{Br}^{-}-$ containing buffer. The inset shows the isolated pre-edge features (asterisk) after removal of the main edge rise. (B) Experimental Fourier-transforms (FTs) of EXAFS spectra in the inset of proteins as in (A) and of oxidized $\mathrm{YdhV}$ in $\mathrm{Cl}^{-}$-free buffer (inset: black lines, experimental data; colored lines, simulations with parameters in Table 3). Arrows emphasize spectral alterations due to the redox or anion changes.

EXAFS analysis was performed to determine the coordination of the Mo ion in the YdhV preparations. The Fourier transform (FT) of the EXAFS spectrum of YdhV ${ }^{\text {ox }}$ revealed 
at least three peak features, suggesting a complex Mo ligation pattern. For YdhV ${ }^{\text {red, }}$ pronounced spectral changes occurred, such as vanishing of the lowest-distance FT peak due to $\mathrm{Mo}=\mathrm{O}$ bonds and increasing of the two higher-distance FT peaks, which indicates significant coordination changes at the metal. The relative FT amplitude patterns and changes were well reproduced in the redox-cycled YdhV. EXAFS simulations provided coordination numbers and interatomic distances in the first and second Mo ligation spheres (Table 3).

Table 3: Mo EXAFS fit parameters of YdhV. ${ }^{\text {a }}$

\begin{tabular}{|c|c|c|c|c|c|}
\hline \multirow{2}{*}{$\begin{array}{c}\text { YdhV } \\
\text { preparation }\end{array}$} & $\mathrm{Mo}=\mathrm{O},-\mathrm{OH}_{\mathrm{n}}$ & $\mathrm{Mo}=\mathrm{S},-\mathrm{SH}$ & Mo-S $\mathrm{S}_{\mathrm{MPT} / \mathrm{Cys}}$ & Mo---Cl,Br & \multirow{2}{*}{$\begin{array}{l}\mathrm{R}_{\mathrm{F}} \\
{[\%]}\end{array}$} \\
\hline & \multicolumn{4}{|c|}{$\mathrm{N}$ [per Mo] / R [̊] / $2 \sigma^{2} \times 10^{3}\left[\AA^{2}\right]$} & \\
\hline $\mathrm{ox}+\mathrm{Cl}$ & $\begin{array}{l}0.7^{\#} / 1.68 / 2^{*} \\
0.4^{\#} / 1.80 / 2^{*}\end{array}$ & $0.3^{\#} / 2.17 / 2^{*}$ & $\begin{array}{l}4.0^{*} / 2.34 / 21 \\
0.6^{\#} / 2.56 / 2^{*}\end{array}$ & $0.5 / 2.88 / 2^{*}$ & 12.4 \\
\hline $\mathrm{red}+\mathrm{Cl}$ & $\begin{array}{l}0.3^{\#} / 1.70 / 2^{*} \\
0.8^{\#} / 2.23 / 2^{*}\end{array}$ & $0.4^{\#} / 2.35 / 2^{*}$ & $\begin{array}{l}4.0^{*} / 2.37 / 14 \\
0.5^{\#} / 2.53 / 2^{*}\end{array}$ & $1.2 / 2.86 / 2^{*}$ & 9.8 \\
\hline rered $+\mathrm{Cl}$ & $\begin{array}{l}0.5^{\#} / 1.70 / 2^{*} \\
0.6^{\#} / 2.14 / 2^{*}\end{array}$ & $0.4^{\#} / 2.29 / 2^{*}$ & $\begin{array}{l}4.0^{*} / 2.39 / 19 \\
0.5^{\#} / 2.55 / 2^{*}\end{array}$ & $1.0 / 2.87 / 2^{*}$ & 11.2 \\
\hline $\mathrm{reox}+\mathrm{Cl}$ & $\begin{array}{l}0.6^{\#} / 1.69 / 2^{*} \\
0.3^{\#} / 1.80 / 2^{*}\end{array}$ & $0.3^{\#} / 2.18 / 2^{*}$ & $\begin{array}{l}4.0^{*} / 2.35 / 17 \\
0.8^{\#} / 2.54 / 2^{*}\end{array}$ & $0.9 / 2.87 / 2^{*}$ & 9.6 \\
\hline $\mathrm{ox}-\mathrm{Cl}$ & $\begin{array}{l}0.8^{\#} / 1.69 / 2^{*} \\
0.2^{\#} / 1.81 / 2^{*}\end{array}$ & $0.4^{\#} / 2.17 / 2^{*}$ & $\begin{array}{l}4.0^{*} / 2.36 / 16 \\
0.6^{\#} / 2.55 / 2^{*}\end{array}$ & $0.2 / 2.84 / 2^{*}$ & 11.5 \\
\hline $\mathrm{ox}+\mathrm{Br}$ & $\begin{array}{l}0.8^{\#} / 1.69 / 2^{*} \\
0.2^{\#} / 1.78 / 2^{*}\end{array}$ & $0.2^{\#} / 2.17 / 2^{*}$ & $\begin{array}{l}4.0^{*} / 2.33 / 19 \\
0.8^{\#} / 2.54 / 2^{*}\end{array}$ & $0.3 / 2.69 / 2^{*}$ & 12.6 \\
\hline red $+\mathrm{Br}$ & $\begin{array}{l}0.4^{\#} / 1.70 / 2^{*} \\
0.8^{\#} / 2.19 / 2^{*}\end{array}$ & $0.3^{\#} / 2.27 / 2^{*}$ & $\begin{array}{l}4.0^{*} / 2.38 / 19 \\
0.5^{\#} / 2.49 / 2^{*}\end{array}$ & $0.7 / 2.67 / 2^{*}$ & 13.4 \\
\hline
\end{tabular}

${ }^{a} \mathrm{~N}$, coordination number; R, interatomic distance; $2 \sigma^{2}$, Debye-Waller factor; $\mathrm{R}_{\mathrm{F}}$, fit error sum (deviation between Fourier back-transform in a 1-3 $\AA$ reduced distance window and simulation curve). Fit restraints: *fixed parameter, "N-values coupled to yield a sum of 2. Parameters correspond to EXAFS simulation curves in the inset of Figure 4B.

First, we searched for a consistent simulation approach that described all spectra well and limited the number of free parameters to gain statistical significance. Unrestraint fits of all spectra provided Mo-S coordination numbers $(N)$ in the range of 3.5-4.1 (not shown). Taking this result and a bis-Mo-MPT structure into account, the $N$-value of the Mo-S $\mathrm{S}_{\text {MPT }}$ shell was restraint to 4. A presumably related cofactor structure in W-containing benzoyl-CoA reductase (BamBC) shows a cysteine bound at the metal, which is also present in the YdhV sequence 
(Figure $\mathrm{S} 1 \mathrm{~A})$, and an oxo ligand $(\mathrm{Mo}=\mathrm{O})$. In other DMSO-reductase family enzymes, a sulfido ligand $(\mathrm{Mo}=\mathrm{S})$ at the metal was found. ${ }^{21,22,36,43-45}$ Accordingly, $\mathrm{Mo}=\mathrm{O} / \mathrm{S}$ distances as well as Mo-S $\mathrm{S}_{\mathrm{Cys}}$ and alternative water or oxygen species were included in the simulations. $\mathrm{YdhV}$ prepared in a $\mathrm{Br}^{-}$instead of $\mathrm{Cl}^{-}$containing buffer revealed pronounced EXAFS spectral changes, in particular increased highest-distance FT peaks (Figure 4), so that a halide in the second Mo coordination sphere was further included. We note that $\mathrm{S}$ and $\mathrm{Cl}^{-}$cannot be discriminated in EXAFS simulations due to their comparable atomic weight, but the heavier backscatterer $\mathrm{Br}^{-}$is well discernable from lighter $\mathrm{Cl}^{-}$species. Table 3 summarizes the simulation results, which show good fit qualities for all spectra as judged by a mean error sum $\left(\mathrm{R}_{\mathrm{F}}\right)$ around $10 \%$.

$\mathrm{YdhV}^{\text {ox }}$ revealed $\sim 0.7 \mathrm{Mo}=\mathrm{O}(\sim 1.7 \AA)$ and $\sim 0.3 \mathrm{Mo}=\mathrm{S}(\sim 2.2 \AA)$ interactions with typical bond lengths, ${ }^{35}$ close to $0.5 \mathrm{Mo}-\mathrm{OH}(\sim 1.8 \AA)$ and Mo-Sys $(\sim 2.6 \AA)$ bonds, and $\leq 0.5 \mathrm{Cl}^{-}$ in the $2^{\text {nd }}$ coordination sphere $(\sim 2.9 \AA)$, besides of the 4 Mo-S $S_{\text {MPT }}(\sim 2.35 \AA)$ bonds (Table 3$)$. In $\mathrm{YdhV}^{\mathrm{red}}$, the number of $\mathrm{Mo}=\mathrm{O}$ bonds decreased in favor of longer $\mathrm{Mo}-\mathrm{OH}_{\mathrm{n}}(\sim 2.2 \AA)$ bonds, short $\mathrm{Mo}=\mathrm{S}$ bonds were replaced by longer Mo-S bonds $(\sim 2.3 \AA)$, the number of Mo-S $\mathrm{S}_{\mathrm{Cys}}$ bonds was diminished, and close to $1 \mathrm{Cl}^{-}$was detectable. $\mathrm{YdhV}^{\text {reox }}$ and $\mathrm{YdhV}^{\text {rered }}$ revealed similar, but less pronounced coordination number and bond lengths changes, including gain of longer Mo-S/O bonds at the expense of shorter $\mathrm{Mo}=\mathrm{O} / \mathrm{S}$ bonds and of the $\mathrm{Cl}^{-}$coordination number in the more reduced enzyme (Table 3). $\mathrm{YdhV}^{\mathrm{ox}}$ prepared in the absence of halides showed a diminished $\mathrm{Cl}^{-}$coordination number and an otherwise similar Mo coordination (Table 3). TXRF on YdhV prepared with $\mathrm{Br}^{-}$instead of $\mathrm{Cl}^{-}$revealed $\sim 0.5 \mathrm{Br}^{-}$per protein (Figure $\mathrm{S} 2$, Table S2). The EXAFS simulations of the spectra of oxidized or reduced YdhV prepared with $\mathrm{Br}^{-}$ showed similar first-sphere coordination and ligation changes as the $\mathrm{Cl}^{-}$containing proteins, including higher numbers of $\mathrm{Mo}=\mathrm{S}$ and $\mathrm{Mo}-\mathrm{S}_{\mathrm{Cys}}$ bonds in the more oxidized enzyme (Table 3). However, about 0.3 or $0.7 \mathrm{Br}^{-}$ions at closer distance to $\mathrm{Mo}(\sim 2.7 \AA)$ vs. $\mathrm{Cl}^{-}$were discernable 
in the oxidized or reduced proteins, in agreement with (partial) replacement of $\mathrm{Cl}^{-}$by $\mathrm{Br}^{-}$in the second Mo coordination sphere.

A bis-Mo-MPT cofactor in $\mathrm{YdhV}$ is further supported by the Mo-S $\mathrm{S}_{\mathrm{MPT}}$ bond numbers and the bond lengths range similar to the highly distorted cofactors in (W) BamBC and AOX crystal structures. ${ }^{16,} 46$ The YdhV preparations likely contain a mixture of Mo site configurations due to varying amounts of oxidized or reduced and of native or modified cofactors. Detection of minor, but reproducible $\mathrm{Mo}=\mathrm{S}$ bond numbers in oxidized $\mathrm{YdhV}$ suggests that a sulfido ligand is present in the native $\mathrm{YdhV}$. The sulfido group is largely replaced by an oxo group in aerobically prepared protein, which further may show cysteine to hydroxo ligand exchange. The sulfido vs. oxo exchange resembles the situation for another DMSOR family enzyme, formate dehydrogenase. ${ }^{36}$ A cysteine ligand seems to be bound to Mo in oxidized $\mathrm{YdhV}$, which may be detached from the metal and replaced, for example, by a water or another amino acid species $\left(\mathrm{O}_{\mathrm{x}}\right)$ in reduced enzyme. Mo site reduction further causes elongation of sulfur and oxygen bonds, which can be explained by ligand protonation to yield Mo-OH $\left(1.9 \AA^{35}\right)$ or Mo-SH $\left(\sim 2.4 \AA^{47,48}\right)$ instead of $\mathrm{Mo}=\mathrm{O}$ or $\mathrm{Mo}=\mathrm{S}$ bonds. In addition, Mo site reduction seems to cause appearance of a halide ion in the $2^{\text {nd }}$ coordination sphere related to cysteine detachment, oxygen species binding, and ligand protonation, which may provide hydrogen-bonding interactions to the halide. Notably, a halide near Mo may be incorporated only in the absence of a substrate. In summary, our results suggest that native, oxidized YdhV contains a $\mathrm{S}=\mathrm{Mo}\left(\mathrm{S}_{\mathrm{cys}}\right)\left(\mathrm{S}_{\mathrm{MPT}}\right)_{4}$ site with $\mathrm{Mo}^{\mathrm{VI}}$, which is converted to a $\mathrm{HS}-\mathrm{Mo}\left(\mathrm{O}_{\mathrm{x}}\right)\left(\mathrm{S}_{\mathrm{MPT}}\right)_{4}$ site presumably with $\mathrm{Mo}^{\mathrm{IV}}$ in reduced enzyme (Figure 5). In modified $\mathrm{YdhV}$, a $\mathrm{O}=\mathrm{Mo}(\mathrm{OH})\left(\mathrm{S}_{\mathrm{MPT}}\right)_{4}$ site in oxidized enzyme seems to be converted to a $\mathrm{HO}-\mathrm{Mo}\left(\mathrm{OH}_{2}\right)\left(\mathrm{S}_{\mathrm{MPT}}\right)_{4}$ site in reduced enzyme. 


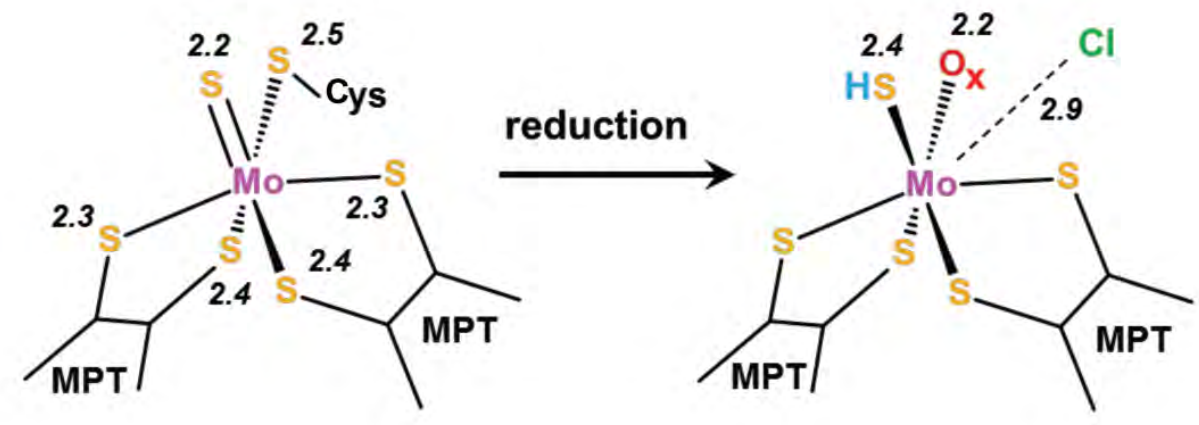

Figure 5: EXAFS-derived molybdenum site structures in YdhV. Schematic drawings tentatively adopt an overall cofactor geometry as in crystal structures of bis-W-MPT-Mg cofactors in BamBC and AOX. Selected (rounded) interatomic distances (in $\AA$ ) from XAS are indicated. The Mo site in native, oxidized $\mathrm{YdhV}$ is proposed to bind sulfido and cysteine (Cys336 in E. coli YdhV) ligands. Sulfur protonation, oxygen against cysteine replacement, and remote halide $\left(\mathrm{Cl}^{-}\right.$or $\mathrm{Br}^{-}$) binding (at an unknown position around the metal) occur upon enzyme reduction; the oxygen species $\left(\mathrm{O}_{\mathrm{x}}\right)$ may stem from water $\left(\mathrm{H}_{2} \mathrm{O}\right)$ or an amino acid residue (e.g. Thr458 in E. coli YdhV). Oxidative modification (i.e. after aerobic enzyme purification) leads to sulfido to oxo and cysteine to hydroxo group exchange at Mo and to further oxygen protonation and/or $\mathrm{O}_{\mathrm{x}}$ as well as halide binding in reduced vs. oxidized enzyme.

\section{XAS on tungsten-substituted YdhV}

XAS spectra of tungsten-substituted, anaerobically purified $\mathrm{YdhV}$ at the $\mathrm{W} \mathrm{L}_{3}$-edge are shown in Figure 6. The W XANES depended strongly on the $\mathrm{W}$ concentration during protein expression. A $\sim 1 \mathrm{eV}$ lower edge energy for $\mathrm{YdhV}$ expressed with $10 \mu \mathrm{M} \mathrm{W}$ vs. $1 \mathrm{mM} \mathrm{W}$ and edge shape changes suggested pronounced coordination changes at the metal. The edge shape for YdhV expressed with $1 \mathrm{mM} \mathrm{W}$ indeed was more similar to tungstate in solution (Figure 6A, see below). The EXAFS spectrum of YdhV expressed with $10 \mu \mathrm{M}$ W revealed a major FT peak due to $\mathrm{W}-\mathrm{S}$ bonds and minor $\mathrm{W}=\mathrm{O}$ contributions (Figure $6 \mathrm{~B}$ ). Simulation of the EXAFS spectrum using a similar approach as for the Mo data revealed $\sim 0.5 \mathrm{~W}=\mathrm{S}(\sim 2.2 \AA), 4 \mathrm{Mo}-\mathrm{S}_{\mathrm{MPT}}$ $(\sim 2.4 \AA)$ and close to $1 \mathrm{Mo}-\mathrm{S}_{\text {cys }}(\sim 2.5 \AA)$ bonds, besides of $\mathrm{W}=\mathrm{O} /-\mathrm{OH}$ bonds. $\mathrm{Cl}^{-}$in the second coordination sphere was barely detectable (Table S3). A more homogenous metal ligation in W vs. Mo YdhV was supported by the smaller Debye-Waller factor $\left(2 \sigma^{2}\right)$ of the W-S

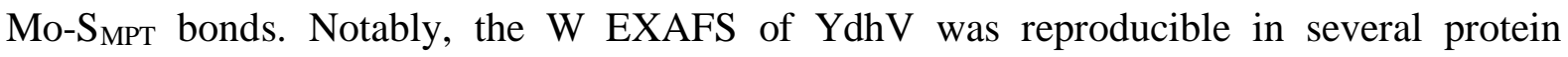
preparations, for cell growth in media with varying tungstate concentrations $\leq 250 \mu \mathrm{M}$, or 
increased salt content in the purification buffer (data not shown). These results suggest that native $\mathrm{YdhV}$ both in the $\mathrm{W}$ and Mo forms shows a fully sulfurated metal site. Oxidative modification was less pronounced for bis-W-MPT samples, facilitating more clear detection of sulfido and cysteine ligands at the tungsten center.

Interestingly, the EXAFS spectrum of YdhV at pH 7.2 expressed with $1 \mathrm{mM}$ W closely resembled the spectrum of tungstate in aqueous solution at $\mathrm{pH} 4.0$ (Figure 6B). EXAFS analysis of $\mathrm{Na}_{2} \mathrm{WO}_{4}$ solutions showed $4 \mathrm{~W}=\mathrm{O}$ bonds at $\mathrm{pH} 10.6$, protonation of one ligand at $\mathrm{pH} 7.1$, but spontaneous tungsten oxide (polytungstate) formation, as evident from $\mathrm{W}-\mathrm{W}$ and long W-O distances in the EXAFS, only at $\mathrm{pH} 4.0$ (Table S3). For YdhV with $1 \mathrm{mM}$ W, no tungsten-sulfur bonds were detectable, which showed the absence of MPT ligands at the metal, but comparable $\mathrm{W}=\mathrm{O} /-\mathrm{OH}_{\mathrm{n}}$ and $\mathrm{W}-\mathrm{W}$ distances as for polytungstate were indicated by the EXAFS simulation. These findings implied that polytungstate formation occurs in the $\mathrm{YdhV}$ protein even at neutral $\mathrm{pH}$. Presumably, in the presence of super-stoichiometric W concentrations during protein expression, the cofactor binding site is occupied by several tungstate molecules, which promotes tungsten-oxide formation in $\mathrm{YdhV}$. 

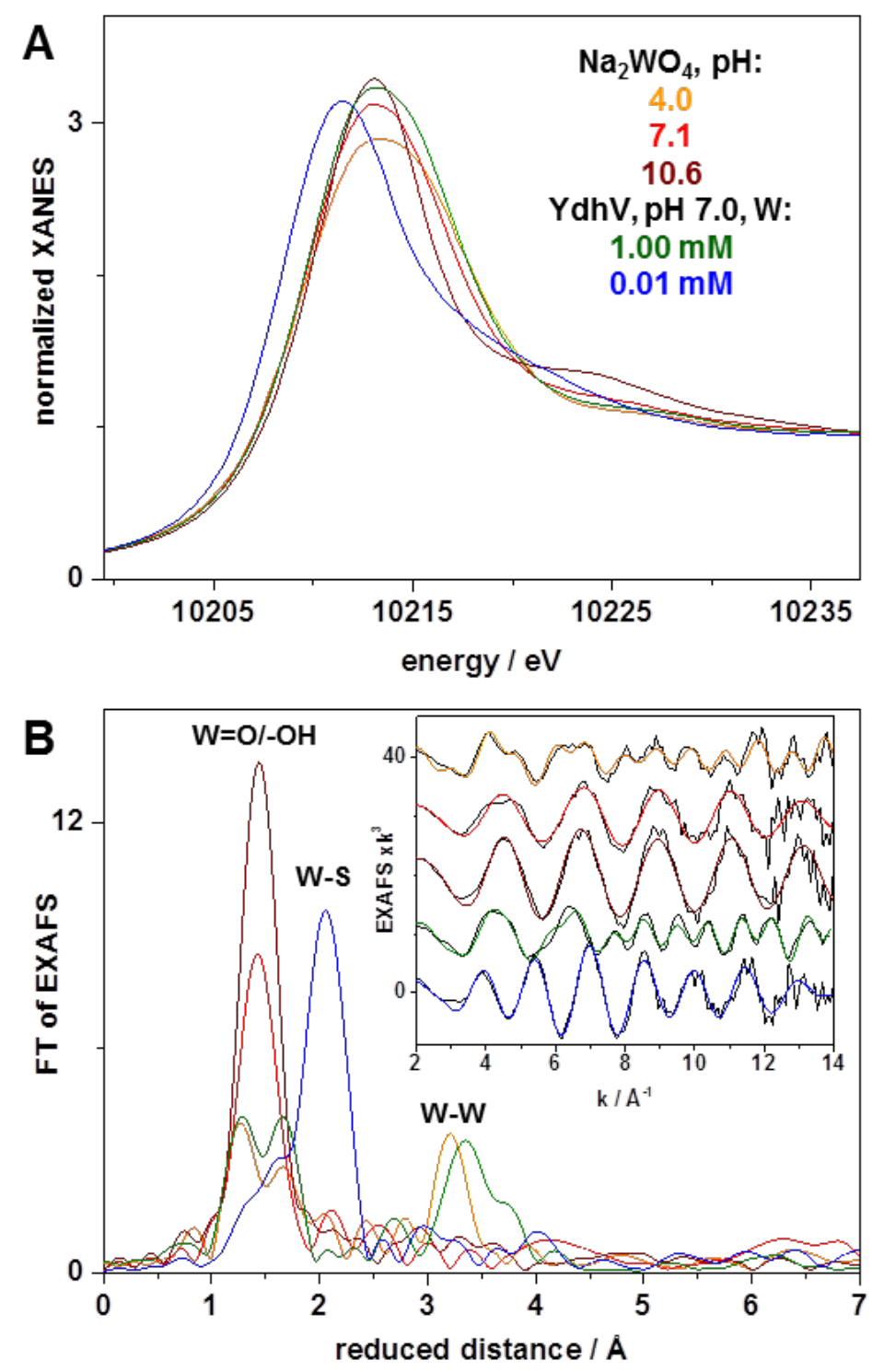

Figure 6: W XAS of YdhV. (A) W $\mathrm{L}_{3}$-edge spectra of YdhV (pH 7.2) expressed with $10 \mu \mathrm{M}$ or $1 \mathrm{mM}$ tungsten (anaerobic purification) compared to spectra of aqueous $\mathrm{Na}_{2} \mathrm{WO}_{4}$ solutions at indicated $\mathrm{pH}$ values. (B) Fourier-transforms (FT) of EXAFS spectra in the inset of samples as in (A) (black lines, experimental data; blue lines, fits with parameters in Table S3; dominant contributions of interatomic distances to the FT peaks are marked).

\section{EPR characterization of $\mathrm{YdhV}$}

To characterize the YdhV protein further, paramagnetic cofactor species were studied by EPR spectroscopy. EPR spectra of Mo(V) in bis-Mo-MPT loaded YdhV are shown in 
Figure 7A. As-isolated and dithionite-reduced YdhV showed an isotropic signal representing less than 0.05 spins/YdhV. This signal was more prominent for purified YdhV expressed in the $\triangle m o a A$ deletion strain (apo-YdhV) in the presence of molybdate, accounting for about 0.1 spins/YdhV or 0.08 spins/Mo in the as-isolated state (Figure S3A; Table S1). Since binding of a bis-Mo-MPT can be excluded in the apo-YdhV variant, the isotropic signal is reminiscent to paramagnetic polymolybdate species reported for the tungstate transporter WtpA. ${ }^{49}$ Therefore, the isotropic signal represents $\mathrm{Mo}(\mathrm{V})$ bound to $\mathrm{YdhV}$ in a non-bis-Mo-MPT form (Figure S3A). Spin quantification of the isotropic signal in the as-isolated, bis-Mo-MPT loaded YdhV revealed approximately $56 \mu \mathrm{M} \mathrm{Mo}(\mathrm{V})$, corresponding to $\sim 15 \%$ of the total molybdenum (Figure 7A, Table S1). Interestingly, upon oxidative treatment with ferricyanide, a more prominent and different signal could be detected, representing a spin concentration of $\sim 0.08$ spins/YdhV at $80 \mathrm{~K}$ and of $\sim 0.20$ spins/YdhV at $150 \mathrm{~K}$ (Figure 7A, Table S1; Figure S4). We assign this signal to $\mathrm{Mo}(\mathrm{V})$ in the bis-Mo-MPT cofactor (see below).

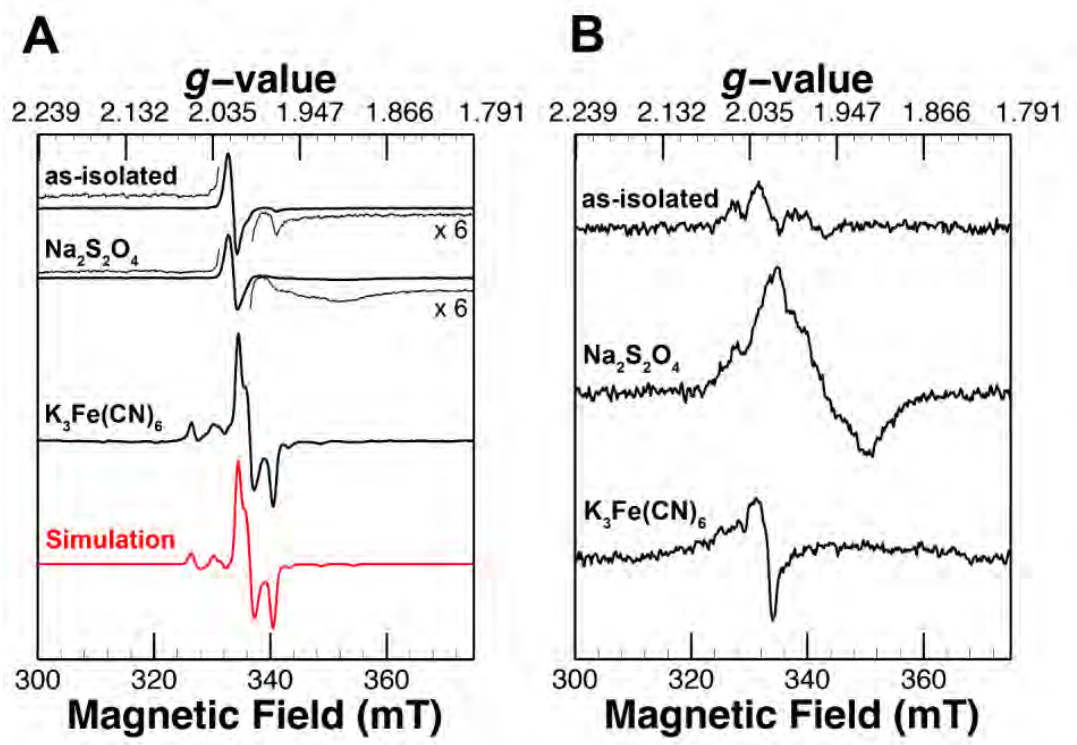

Figure 7: X-band EPR spectra of YdhV. Anaerobically expressed and purified YdhV was employed. (A) YdhV expressed in the presence of $1 \mathrm{mM} \mathrm{Na}_{2} \mathrm{MoO}_{4}$, (B) $\mathrm{YdhV}$ expressed in the presence of $10 \mu \mathrm{M} \mathrm{Na} \mathrm{WO}_{4}$. Spectral simulation of $\mathrm{Mo}(\mathrm{V})$ detected in ferricyanideoxidized YdhV. The black spectra depict YdhV as-isolated (top), after treatment with $10 \mathrm{mM}$ sodium dithionite (middle), and after treatment with $\mathrm{K}_{3} \mathrm{Fe}(\mathrm{CN})_{6}$ (bottom); the red spectrum in panel A represents a spectral simulation of the ferricyanide-oxidized spectrum. Features present in the baseline are enlarged as noted (thin lines). Spectra were recorded at $80 \mathrm{~K}$ (4 mW microwave power, $5 \mathrm{G}$ modulation amplitude, $100 \mathrm{kHz}$ modulation frequency). Spectra in 
panel A represent a YdhV concentration of $202 \mu \mathrm{M}$; spectra in panel B were scaled to comparable amplitudes for comparison. For associated concentrations of Mo and Fe, see Table S1:

By contrast, in EPR spectra of bis-W-MPT loaded YdhV no W(V) was detected (Figure 7B). These results possibly reflect a less redox-active bis-W-MPT as opposed to a more redox-active bis-Mo-MPT cofactor.

A spectral simulation of the $\mathrm{Mo}(\mathrm{V})$ signal in ferricyanide-treated $\mathrm{YdhV}$ is shown in Figure 7A (see also Figure S4). The simulation parameters $\left(g=2.0082,1.9957,1.9724 ; g_{\mathrm{av}}=\right.$ 1.9915) yielded a tensor reminiscent in anisotropy and rhombicity to parameters reported for the glycerol-inhibited and "high-g unsplit" $\mathrm{Mo}(\mathrm{V})$ states detected in $R$. sphaeroides DMSO reductase (Table S4). ${ }^{50,51}$ Inclusion of a $\mathrm{Mo}(\mathrm{V})$ component due to unspecific molybdenum was not necessary to achieve a good simulation and resolved ${ }^{1} \mathrm{H}$ hyperfine couplings were not observed. ${ }^{35,37}$ Inclusion of chloride hyperfine coupling also did not improve the simulation. The ${ }^{95,97}$ Mo hyperfine tensor $\left(\mathrm{A}^{\mathrm{Mo}}=[75.7,152.5,6.1] \mathrm{MHz}\right)$ exhibits rhombic character. Rhombic ${ }^{95,97}$ Mo hyperfine tensors typically show a lowered point group symmetry due to trigonalprismatic metal coordination through distortion of the Mo-S $\mathrm{S}_{\mathrm{MPT}}$ from a formally trigonalprismatic metal coordination geometry. ${ }^{51}$ In turn, the simulated hyperfine parameters for the $\operatorname{Mo}(\mathrm{V})$ bis-Mo-MPT center are reflective of a low-symmetry structure.

The power saturation behavior of the $\mathrm{Mo}(\mathrm{V})$ species was studied (Figure $8 \mathrm{~A})$. The $\mathrm{Mo}(\mathrm{V})$ signal (at $12 \mathrm{~K}$ ) of ferricyanide-treated $\mathrm{YdhV}$ exhibited a half-saturation power $\left(P_{1 / 2}\right)$ of $90 \mathrm{~mW}$, meaning that the signal was very difficult to saturate. While an interacting Fe-S cluster can be ruled out as a reason for relaxation enhancement of the $\mathrm{Mo}(\mathrm{V})$ signal since the cluster in YdhV (see below) was oxidized, apparent coupling to ferricyanide ions may cause the large $\mathrm{P}_{1 / 2}$ (Figure S5, panel A). Indeed, removal of ferricyanide from the YdhV sample resulted in a dramatically slowed relaxation of the $\mathrm{Mo}(\mathrm{V})$ signal at $12 \mathrm{~K}$ without significant change in shape of signal, which now showed an about 135 -fold smaller $P_{1 / 2}$ value $(670 \mu \mathrm{W})$. 
The latter value is similar to the $\mathrm{Mo}(\mathrm{V})$ signal of $E$. coli DMSO reductase in the presence of an oxidized [4Fe-4S] cluster. $^{52}$ These observations are consistent with the binding of ferricyanide ions in proximity to molybdenum in $\mathrm{YdhV}$, resulting in an apparent $\mathrm{Fe}(\mathrm{III})-\mathrm{Mo}(\mathrm{V})$ electron spin-spin interaction.
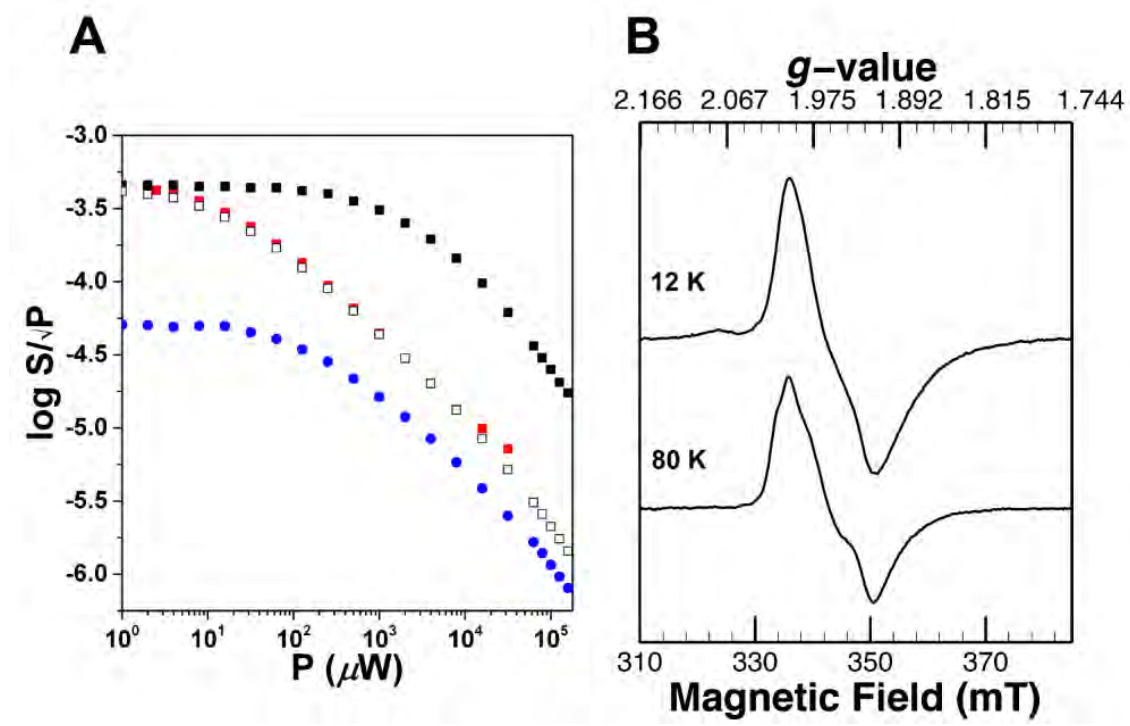

Figure 8: Relaxation behavior of paramagnetic species in YdhV. Panel A depicts the power saturation properties of Mo(V)-associated (squares) and Fe-S cluster-associated (circles) EPR signals recorded at $12 \mathrm{~K}$ (10 G modulation amplitude, $100 \mathrm{kHz}$ modulation frequency). Solid squares represent the intensity of the bis-Mo-MPT Mo(V) signals (Figure 7, panel A) recorded in the presence (black squares) or absence (red squares) of $\mathrm{K}_{3} \mathrm{Fe}(\mathrm{CN})_{6}$ (measured at $334.5 \mathrm{mT}$ ). Open squares represent the intensity of the signal of unspecific $\mathrm{Mo}(\mathrm{V})$ in apo-YdhV expressed in the presence of molybdate (measured at $335.0 \mathrm{mT}$; Figure S3, panel A). Solid circles represent the intensity of the EPR signal at $12 \mathrm{~K}$ attributable to an Fe-S cluster in YdhV (measured at $336.0 \mathrm{mT}$; Figure S3, panel B). Panel B shows EPR signals at two temperatures of apo-YdhV aerobically expressed without $\mathrm{Na}_{2} \mathrm{MoO}_{4}$ and reduced with $10 \mathrm{mM}$ sodium dithionite (see also Figure S3, panel B) ( $4 \mathrm{~mW}$ microwave power, $10 \mathrm{G}$ modulation amplitude, $100 \mathrm{kHz}$ modulation frequency). Shown spectra are baseline-corrected. For concentrations of Mo and Fe in the EPR samples, see Table S1.

\section{Fe XAS analysis}

In addition to molybdenum, $\mathrm{YdhV}$ was found to also bind about 2-3 $\mathrm{Fe}$ ions per protein (Table S1). Sequence alignment revealed a 46\% amino acid sequence homology of YdhV with the benzoyl-CoA reductase BamBC from G. metallireducens (Figure S1A) particularly in that the YdhV residues Cys307, Cys310, Cys314, and Cys558 are similar to those shown to 
coordinate a $[4 \mathrm{Fe}-4 \mathrm{~S}]$ cluster in proximity to the bis-W-MPT-Mg cofactor in the crystal structure of BamBC (Figure S1B). ${ }^{17}$ To identify the Fe-S cluster type of YdhV, XAS data at the Fe K-edge were collected (Figure 9). The XANES spectrum shows the typical shape of predominately sulfur-coordinated, tetrahedral iron. ${ }^{53,} 54$ The EXAFS Fourier-transform displays two main peak features mainly due to Fe-S and Fe-Fe distances. Simulation of the EXAFS spectrum revealed less than 4 Fe-S bonds $(\sim 2.2-2.4 \AA)$, about $1 \mathrm{Fe}-\mathrm{O}$ bond $(\sim 2.5 \AA)$, and $\sim 1.6 \mathrm{Fe}-\mathrm{Fe}$ distances $(\sim 2.7 \AA)$, as well as longer Fe-C distances per iron ion (Table S5). The interatomic distances are typical for iron-sulfur clusters, but the coordination numbers deviate from the values expected for a $[4 \mathrm{Fe}-4 \mathrm{~S}]$ cluster (4 Fe-S bonds, $3 \mathrm{Fe}-\mathrm{Fe}$ distances) or a [2Fe-2S] cluster (4 Fe-S bonds, $1 \mathrm{Fe}-\mathrm{Fe}$ distance). Taking into account the sub-stoichiometric Fe content, the detectable Fe-O bonds, and the presence of four cysteines in YdhV, it seems likely that the Fe EXAFS represents an overlay of partially assembled and (oxidatively) degraded $[4 \mathrm{Fe}-4 \mathrm{~S}]$ clusters, explaining the non-integer Fe-Fe coordination number and fractional oxygen-ligation of iron.
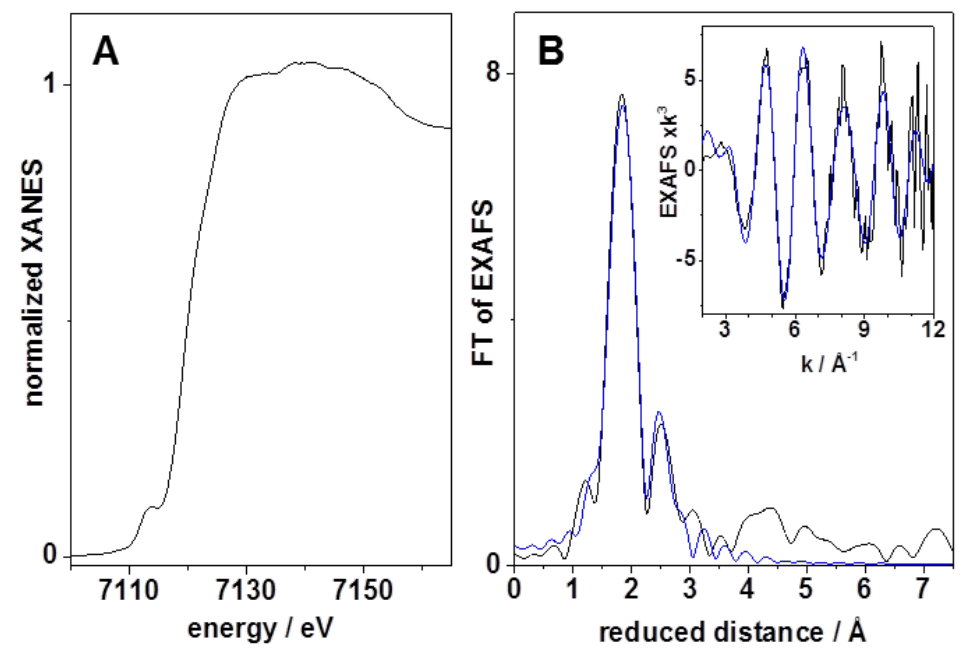

Figure 9: Fe XAS of YdhV. (A) Fe K-edge spectrum. (B) Fourier-transform (FT) of EXAFS spectrum in the inset (black lines, experimental data; blue lines, simulation with parameters in Table S5; the first FT peak reflects Fe-S,O bonds and the second peak Fe-Fe,C distances). The FT was calculated for a k-range of 2-12 $\AA^{-1}$ (cos windows of $10 \%$ at both k-range ends).

EPR spectroscopy of the FeS cluster present in YdhV 
EPR spectroscopy was employed to further characterize [4Fe-4S] cluster binding to YdhV. To unambiguously differentiate spectral features associated with an Fe-S cluster, the apo-YdhV variant expressed in the absence of molybdate was characterized, that exhibited comparable Fe loading and substantially decreased Mo loading relative to bis-Mo-MPT-loaded YdhV (Table S1). Dithionite-reduced apo-YdhV revealed a broad EPR signal at $12 \mathrm{~K}$ and 4 $\mathrm{mW}$ microwave power, but did not show the isotropic signal observed for bis-Mo-MPT-loaded YdhV measured under similar conditions (Figure 8B, see also Figure S3B). To identify the FeS cluster type bound to apo-YdhV, EPR power saturation and temperature dependence studies were performed. EPR power saturation measurements at $12 \mathrm{~K}$ yielded a $P_{1 / 2}$ of $1.5 \mathrm{~mW}$, a value qualitatively similar to [2Fe-2S] clusters (Figure $8 \mathrm{~A}$ ); by comparison, the $12 \mathrm{~K}$ and $80 \mathrm{~K}$ spectra appeared similar with modest changes in the signal lineshape and similar spin concentrations ( 0.08-0.09 spins/YdhV) were observed under power non-saturating conditions (Table S1). These observations, in conjunction with the lowered Fe content (Table S1), XAS results, and featureless optical absorption spectra (Figure 2C) are consistent with an apparent [2Fe-2S] cluster of low occupation in YdhV. Likely, such a cluster reflects a species that has resulted from partial degradation of a $[4 \mathrm{Fe}-4 \mathrm{~S}]$ cluster as favored by the amino acid sequence of YdhV. 


\section{DISCUSSION}

The variety of molybdoenzymes seems to be more versatile than originally expected, since we identified a novel bis-Mo-MPT cofactor without attached nucleotides in E. coli $\mathrm{YdhV}$. A bis-Mo-MPT cofactor was consistently indicated by elemental analysis, nucleotide detection methods, and XAS. So far, the insertion of tungsten into the MPT cofactor of various molybdoenzymes was assumed to occur only unspecifically in E. coli (e.g. under high tungstate concentrations of $1-5 \mathrm{mM}$ during expression). Our results reveal assembly of a bis-W-MPT cofactor in YdhV even for low tungstate concentrations $(10 \mu \mathrm{M})$. However, when both Mo and W were present, molybdenum is preferred over tungsten binding in $\mathrm{YdhV}$. We therefore conclude that $\mathrm{YdhV}$ binds preferentially molybdenum so that under typical E. coli growth conditions, a bis-Mo-MPT cofactor is bound to the enzyme. The bis-Mo-MPT cofactor revealed to be redox active both in XAS and EPR spectroscopy, featuring (likely predominant) $\mathrm{Mo}(\mathrm{IV})$ and (minor) Mo(V) species, whereas EPR showed no indication for $\mathrm{W}(\mathrm{V})$ species of the bis-W-MPT cofactor. These findings suggest that a Mo(V) species may be involved as a semi-stable state in the two-electron reduction of the bis-Mo-MPT cofactor whereas the bisW-MPT cofactor is either redox-inert or a $\mathrm{W}(\mathrm{V})$ species is less stable than the Mo(V) species.

In previous studies by our group, a bis-Mo-MPT cofactor was identified as an intermediate in the synthesis of the bis-MGD cofactor in $E$. coli, a reaction that is catalyzed by the MobA protein. In bis-MGD synthesis, two Mo-MPT molecules are fused on MobA to form the bis-Mo-MPT structure before nucleotide addition. For this reaction the ligation of molybdenum to MPT is essential. ${ }^{13}$ After formation of bis-Mo-MPT, two equivalents of GMP (from GTP) are added to the C4' phosphate of each MPT and the bis-MGD cofactor is formed. Our present results, however, reveal that formation of the bis-Mo-MPT cofactor in YdhV is independent of MobA. Also, the homologous protein MocA, which is involved in MCD cofactor formation in enzymes of the XO family, is likewise not involved in bis-Mo-MPT 
synthesis in YdhV. This situation might indicate that either other proteins in E. coli are involved in bis-Mo-MPT formation or that this cofactor is directly formed on YdhV. So far, no function has been assigned for the two proteins YdhW and YdhT also encoded by the $y d h Y V W X U T$ operon. Amino acid sequence alignments show limited sequence identities of YdhW and YdhT with MobA. Thus, it is possible that YdhW and YdhT represent two proteins that act in conjunction in the formation of the bis-Mo-MPT cofactor in $\mathrm{YdhV}$.

Despite extensive experimental efforts, we were unable to assign any substrate to YdhV. Previous studies by our group showed that the $y d h Y V W X U T$ operon is induced under anaerobic conditions, pointing to a role in anaerobic respiration. ${ }^{55}$ Using XAS and EPR we demonstrated that the molybdenum atom in the bis-Mo-MPT cofactor of YdhV shows reversible redox activity. Our XAS results suggest that the Mo coordination sphere in the bisMo-MPT cofactor comprises a similar cysteine ligand as present in the homologous benzoylCoA reductase BamBC, in addition to a sulfido ligand. However, the sulfido ligand is easily replaced by an oxo ligand when $\mathrm{YdhV}$ is aerobically purified. In tungsten-containing $\mathrm{YdhV}$ an enhanced sulfido ligand content was observed. These findings suggest that the native $\mathrm{YdhV}$ active site contains a Mo-ligation sphere resembling that of formate dehydrogenases, which also bind either tungsten or molybdenum as well as cysteine and sulfido ligands at the metal in the bis-MGD cofactor (Figure 5). We note that the nature of the sixth ligand at the metal in the homologous enzyme BamBC remains to be established while cysteine ligation is visible in the crystal structure. A recent theoretical investigation disfavored a sulfido ligand in BamBC and favored an oxo ligand. ${ }^{56}$ However, such a coordination sphere might be unique to BamBC since the particular Birch reaction catalysed by this enzyme so far is unique among molybdenum and tungsten enzymes. ${ }^{57}$ The bis-W-MPT cofactor in BamBC contains a magnesium atom bridging the phosphate groups of the two pterin moieties. The methionine and serine residues binding $\mathrm{Mg}^{2+}$ in BamBC are conserved also in $\mathrm{YdhV}$ (Figures S1A and B), suggesting a similar 
cofactor structure. Interestingly, we have obtained evidence that a halide ion $\left(\mathrm{Cl}^{-}\right.$or $\left.\mathrm{Br}^{-}\right)$may be present in the second metal coordination sphere in reduced YdhV. The presence of at least spurious chloride is difficult to exclude under the usual cell growth and protein expression/purification conditions. It should be noted, however, that the detected $\mathrm{Mo}(\mathrm{V})$ for YdhV displays no (large) hyperfine coupling to a chloride ion directly detectable in the EPR spectrum, at least in comparison to the coupling situation shown for $\mathrm{Mo}(\mathrm{V})$ in sulfite oxidase. ${ }^{58-}$ ${ }^{62}$ Presumably, chloride may occupy a putative binding site close to the metal center only when it is in the Mo(IV) state and when a catalytically competent substrate is absent. Further studies are required to clarify a potential role of halides in $\mathrm{YdhV}$.

EPR characterization of $\mathrm{YdhV}$ has provided distinct insights on paramagnetic molybdenum and iron species in comparison to other molybdenum enzymes. The signal of the $\mathrm{Mo}(\mathrm{V})$ species in the bis-Mo-MPT cofactor of YdhV resembles the high-pH signal of $E$. coli nitrate reductase $\mathrm{NarGH}^{63}$ and the "high-g-unsplit" signal of DMSO reductase from E. coli, $R$. sphaeroides, or $R$. capsulatus, ${ }^{50-52,64,65}$ likely reflecting a similar $\mathrm{Mo}(\mathrm{V})$ coordination geometry in these enzymes. It should be noted that the coordination sphere of the aforementioned enzymes are thought to have a mixed sulfur/oxygen coordination geometry, with respect to binding of an oxo ligand and either a coordinated serine or aspartate residue. The $g$-matrix and hyperfine coupling parameters of the $\mathrm{YdhV} \mathrm{Mo}(\mathrm{V})$ are reminiscent of the Mo(V) species of $R$. sphaeroides DMSO reductase generated in the presence of TMAO, albeit without observable ${ }^{1} \mathrm{H}$ hyperfine coupling. By comparison, the slightly elevated $g_{\text {av }}$ value and altered $g$-tensor anisotropy in YdhV relative to DMSO reductase likely is due to coordination of the cysteine thiolate. ${ }^{51}$ A similarly rhombic ${ }^{95,97}$ Mo hyperfine tensor likely reflects low coordination symmetry at the metal. As has been shown for the high- and low-pH Mo(V) EPRsignals of $E$. coli nitrate reductase, the dihedral angle between the oxo and aspartate ligands can modulate the $\mathrm{Mo}(\mathrm{V}) g$-values and the isotropic proton hyperfine interaction. ${ }^{66}$ The 
geometry of the two apical Mo(V) ligands may therefore also affect the EPR parameters of $\mathrm{Mo}(\mathrm{V})$ inYdhV.

Based on EPR spin Hamiltonian parameters for bis-MGD enzymes in literature, two tentative Mo(V) coordination structures are conceivable for YdhV (Figure 10C,D).

A

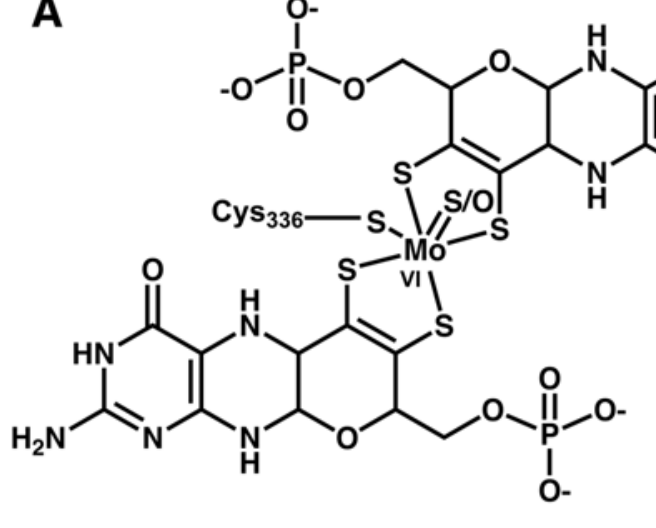

C

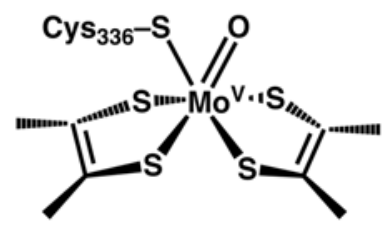

B

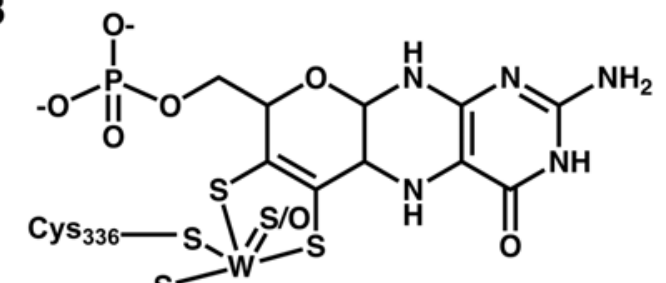<smiles>CC1=C2CC3Nc4c(nc(N)[nH]c4=O)NC4OC(COP(=O)([O-])O)C2=C3SC4=N1</smiles>

D

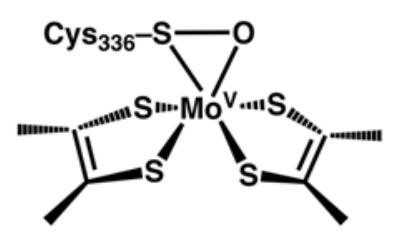

Figure 10. Proposed bis-Mo-MPT and bis-W-MPT structures of YdhV. Panels A and B depict (schematic) structures of bis-Mo/W-MPT cofactors $\left(\mathrm{Mo}^{\mathrm{VI}}\right)$ suggested by our XAS and biochemical results while panels $\mathrm{C}$ and $\mathrm{D}$ depict possible cofactor structures in agreement with our EPR results (paramagnetic $\mathrm{Mo}^{\mathrm{V}}$; the EPR data reflect a mixed O/S coordination with respect to binding of the Cys336 thiolate and an oxo ligand; the apparent lack of ${ }^{1} \mathrm{H}$ hyperfine coupling may occur for example via C) oxo ligand binding, or via D) sulfoxygenated Cys336 binding).

Given that YdhV coordinates a bis-Mo-MPT cofactor, a coordination geometry with four Mo$\mathrm{S}_{\mathrm{MPT}}$ bonds is most likely. The determined spin Hamiltonian parameters of the Mo(V) appear consistent with a mixed $\mathrm{O} / \mathrm{S}$ coordination geometry with respect to binding of an oxo or a sulfido ligand, in addition to binding of the Cys336 ligand, in agreement with the XAS data. Binding of the Cys thiolate to the bis-Mo-MPT is further supported by a relatively elevated $g_{\mathrm{av}}$ reminiscent to bis-MGD enzymes such as for formate dehydrogenases that coordinate a Cys thiolate ligand and a sulfido ligand. ${ }^{36}$ Similary, the arsenate reductase $\mathrm{Mo}(\mathrm{V})$ in complex with 
arsenite shows a very similar $\mathrm{Mo}(\mathrm{V}) \mathrm{g}$-tensor as $\mathrm{YdhV}$, with a coordinated cysteine thiolate and coupling to a ${ }^{75} \mathrm{As}$ center. ${ }^{67}$ Completing the coordination sphere, an oxo ligand is considered here, since the sulfido ligand was detected as a minor species. The apparent absence of substantial ${ }^{1} \mathrm{H}$ hyperfine coupling may be explained by a structure with an oxo ligand, as opposed to a hydroxo or water ligand. Alternatively, a sulfoxygenated cysteine thiolate, as found, e.g., in [NiFeSe] hydrogenases ${ }^{68}$ and $\mathrm{NAD}^{+}$-reducing $[\mathrm{NiFe}]$ hydrogenases, ${ }^{69}$ might be possible. In conclusion, although the detected $\mathrm{Mo}(\mathrm{V})$ species represents a minor cofactor population, the properties of this Mo-MPT cofactor state in $\mathrm{YdhV}$ are comparable to $\mathrm{Mo}(\mathrm{V})$ species of bis-MGD cofactors in other enzymes. ${ }^{70}$

Our apparent failure to identify any substrate reactions of YdhV may be explained by the lack of a functional [4Fe-4S] cluster in proximity to the bis-Mo-MPT cofactor. The amino acid sequence, in homology to BamBC and other enzymes, shows four cysteine residues that could bind a [4Fe-4S]-cluster in YdhV. However, even in anaerobically expressed and purified $\mathrm{YdhV}$, the Fe-S cluster may be partially disassembled even by very minor residual $\mathrm{O}_{2}$ contaminations. Characterization of the iron-sulfur cluster in YdhV by XAS and EPR revealed an apparent $[2 \mathrm{Fe}-2 \mathrm{~S}]$ species of low occupation, that likely has resulted from degradation of a [4Fe-4S] cluster. The apparently extreme sensitivity of the [4Fe-4S] cluster towards degradation may suggest that YdhV belongs to the group of enzymes that contain a so-called "hyper-active" cysteine residue according to a bioinformatics analysis. ${ }^{71}$ Such a cysteine may enhance [4Fe-4S]-cluster degradation also in YdhV.

In conclusion, our results reveal that YdhV belongs to a novel class of molybdenum oxidoreductases in E. coli that comprises a bis-Mo-MPT cofactor with a cysteine and a sulfido ligand at the metal (Figure 10) as well as likely a [4Fe-4S]-cluster, which is particularly sensitive to partial degradation. The enzyme binds preferentially molybdenum in the cofactor, but a similar cofactor with a tungsten center is formed when only tungsten is available (Figure 
10). Accordingly, E. coli is able to assemble not only molybdenum-, but also tungstencontaining cofactors. The presence of a Mo/W containing bis-MPT cofactor in E. coli opens a new route of Moco biosynthesis and expands the canon of the versatile molybdenum and tungsten enzymes.

\section{AUTHOR INFORMATION}

\section{Corresponding Authors}

*Phone: +49 331977 5603. E-mail: sleim@uni-potsdam.de (S. Leimkühler).

*Phone: +49 30838 56101. E-mail: michael.haumann@fu-berlin.de (M. Haumann).

\section{Funding}

This work was supported by the Berlin Cluster of Excellence 314 "Unicat" (to S.L., C.T., M.H, and H.D.) and DFG grant LE1171/6-2 to SL.

\section{Notes}

The authors declare no competing financial interest.

\section{ACKNOWLEDGMENTS}

We gratefully acknowledge technical assistance by Natalie Lupilov (Ruhr University Bochum). We thank Tanja Schwerdtle and Sören Meyer (University of Potsdam) for help with ICP-MS analyses. We thank the beamline teams at Soleil (Samba; E. Fonda, A. Zitolo) and BESSY (KMC-3; I. Zizak, G. Schuck) for excellent technical support and N. Schuth for assistance in XAS data collection. 


\section{ABBREVIATIONS}

bis-MPT guanine dinucleotide (bis-MGD)

cyclic pyranopterin monophosphate (cPMP)

cytosine dinucleotide (MCD)

electron paramagnetic resonance spectroscopy (EPR)

extended X-ray absorption fine structure (EXAFS)

iron-sulfur (Fe-S)

metal-binding pterin (MPT)

molybdenum cofactor (Moco)

trimethyl-N-oxide (TMAO)

X-ray absorption spectroscopy (XAS)

X-ray absorption near edge structure (XANES) 
Supporting Information Available

\section{TABLES}

Table S1: YdhV metal quantification and spin concentrations from EPR.

Table S2: Element contents in YdhV from TXRF.

Table S3: W EXAFS simulation parameters.

Table S4: Comparison of spin Hamiltonian parameters for selected molybdoenzymes.

Table S5: Fe EXAFS simulation parameters of YdhV.

\section{FIGURES}

Figure S1: Sequence alignment of YdhV and BamBC (A) and crystal structure of $\operatorname{BamBC}(\mathbf{B})$.

Figure S2: Elemental analysis with TXRF.

Figure S3. X-band EPR spectra of apo-YdhV.

Figure S4. EPR spectral simulation of the Mo(V) signal of ferricyanide-oxidized YdhV at $150 \mathrm{~K}$.

Figure S5: Wide-sweep X-band EPR spectra of YdhV at low temperature. 


\section{References}

[1] Hille, R., Hall, J., and Basu, P. (2014) The mononuclear molybdenum enzymes, Chemical reviews 114, 3963-4038.

[2] Mendel, R. R., and Leimkühler, S. (2015) The biosynthesis of the molybdenum cofactors, J Biol Inorg Chem 20, 337-347.

[3] Hille, R. (1996) The mononuclear Mo enzymes, In Chem. Rev., pp 2757-2816.

[4] Massey, V., and Edmondson, D. (1970) On the mechanism of inactivation of xanthine oxidase by cyanide, J. Biol. Chem. 245, 6595-6598.

[5] Iobbi-Nivol, C., and Leimkuhler, S. (2013) Molybdenum enzymes, their maturation and molybdenum cofactor biosynthesis in Escherichia coli, Biochim Biophys Acta 1827, 1086-1101.

[6] Neumann, M., Mittelstadt, G., Seduk, F., Iobbi-Nivol, C., and Leimkuhler, S. (2009) MocA is a specific cytidylyltransferase involved in molybdopterin cytosine dinucleotide biosynthesis in Escherichia coli, The Journal of biological chemistry 284, 2189121898.

[7] Reschke, S., Sigfridsson, K. G., Kaufmann, P., Leidel, N., Horn, S., Gast, K., Schulzke, C., Haumann, M., and Leimkuhler, S. (2013) Identification of a Bis-molybdopterin Intermediate in Molybdenum Cofactor Biosynthesis in Escherichia coli, The Journal of biological chemistry 288, 29736-29745.

[8] Neumann, M., Seduk, F., Iobbi-Nivol, C., and Leimkuhler, S. (2011) Molybdopterin dinucleotide biosynthesis in Escherichia coli: identification of amino acid residues of molybdopterin dinucleotide transferases that determine specificity for binding of guanine or cytosine nucleotides, The Journal of biological chemistry 286, 1400-1408.

[9] Johnson, J. L., Bastian, N. R., and Rajagopalan, K. V. (1990) Molybdopterin guanine dinucleotide: a modified form of molybdopterin identified in the molybdenum cofactor of dimethyl sulfoxide reductase from Rhodobacter sphaeroides forma specialis denitrificans, Proceedings of the National Academy of Sciences of the United States of America 87, 3190-3194.

[10] Johnson, J. L., Indermaur, L. W., and Rajagopalan, K. V. (1991) Molybdenum cofactor biosynthesis in Escherichia coli. Requirement of the chlB gene product for the formation of molybdopterin guanine dinucleotide, The Journal of biological chemistry 266, 12140-12145.

[11] Rajagopalan, K. V., and Johnson, J. L. (1992) The pterin molybdenum cofactors, The Journal of biological chemistry 267, 10199-10202.

[12] Borner, G., Karrasch, M., and Thauer, R. K. (1991) Molybdopterin adenine dinucleotide and molybdopterin hypoxanthine dinucleotide in formylmethanofuran dehydrogenase from Methanobacterium thermoautotrophicum (Marburg), FEBS letters 290, 31-34.

[13] Temple, C. A., and Rajagopalan, K. V. (2000) Mechanism of assembly of the Bis(Molybdopterin guanine dinucleotide)molybdenum cofactor in Rhodobacter sphaeroides dimethyl sulfoxide reductase, The Journal of biological chemistry 275, 40202-40210.

[14] Palmer, T., Santini, C.-L., Iobbi-Nivol, C., Eaves, D. J., Boxer, D. H., and Giordano, G. (1996) Involvement of the narJ and mob gene products in the biosynthesis of the molybdoenzyme nitrate reductase in Escherichia coli, Mol Microbiol 20, 875-884.

[15] Lake, M. W., Temple, C. A., Rajagopalan, K. V., and Schindelin, H. (2000) The crystal structure of the Escherichia coli MobA protein provides insight into molybdopterin guanine dinucleotide biosynthesis, The Journal of biological chemistry 275, 4021140217. 
[16] Chan, M. K., Mukund, S., Kletzin, A., Adams, M. W. W., and Rees, D. C. (1995) Structure of a hyperthermophilic tungstopterin enzyme, aldehyde ferredoxin oxidoreductase, Science 267, 1463-1469.

[17] Kung, J. W., Loffler, C., Dorner, K., Heintz, D., Gallien, S., Van Dorsselaer, A., Friedrich, T., and Boll, M. (2009) Identification and characterization of the tungsten-containing class of benzoyl-coenzyme A reductases, Proc Natl Acad Sci U S A 106, 17687-17692.

[18] Leimkühler, S., and Iobbi-Nivol, C. (2016) Bacterial molybdoenzymes: old enzymes for new purposes, FEMS microbiology reviews 40, 1-18.

[19] Neumann, M., Mittelstadt, G., Iobbi-Nivol, C., Saggu, M., Lendzian, F., Hildebrandt, P., and Leimkuhler, S. (2009) A periplasmic aldehyde oxidoreductase represents the first molybdopterin cytosine dinucleotide cofactor containing molybdo-flavoenzyme from Escherichia coli, The FEBS journal 276, 2762-2774.

[20] Gennaris, A., Ezraty, B., Henry, C., Agrebi, R., Vergnes, A., Oheix, E., Bos, J., Leverrier, P., Espinosa, L., Szewczyk, J., Vertommen, D., Iranzo, O., Collet, J. F., and Barras, F. (2015) Repairing oxidized proteins in the bacterial envelope using respiratory chain electrons, Nature 528, 409-412.

[21] Kaufmann, P., Duffus, B. R., Mitrova, B., Iobbi-Nivol, C., Teutloff, C., Nimtz, M., Jansch, L., Wollenberger, U., and Leimkuhler, S. (2018) Modulating the Molybdenum Coordination Sphere of Escherichia coli Trimethylamine N-Oxide Reductase, Biochemistry 57, 1130-1143.

[22] Coelho, C., Gonzalez, P. J., Moura, J. G., Moura, I., Trincao, J., and Joao Romao, M. (2011) The crystal structure of Cupriavidus necator nitrate reductase in oxidized and partially reduced states, Journal of molecular biology 408, 932-948.

[23] Raaijmakers, H. C., and Romao, M. J. (2006) Formate-reduced E. coli formate dehydrogenase $\mathrm{H}$ : The reinterpretation of the crystal structure suggests a new reaction mechanism, J Biol Inorg Chem 11, 849-854.

[24] Partridge, J. D., Browning, D. F., Xu, M., Newnham, L. J., Scott, C., Roberts, R. E., Poole, R. K., and Green, J. (2008) Characterization of the Escherichia coli K-12 ydhYVWXUT operon: regulation by FNR, NarL and NarP, Microbiology 154, 608618.

[25] George, G. N., Prince, R. C., Mukund, S., and Adams, M. W. W. (1992) Aldehyde ferredoxin oxidoreductase from the hyperthermophilic archaebacterium Pyrococcus furiosus contains a tungsten oxo-thiolate center, J. Am. Chem. Soc. 114, 3521-3523.

[26] Baba, T., Ara, T., Hasegawa, M., Takai, Y., Okumura, Y., Baba, M., Datsenko, K. A., Tomita, M., Wanner, B. L., and Mori, H. (2006) Construction of Escherichia coli K-12 in-frame, single-gene knockout mutants: the Keio collection, Molecular systems biology 2, 20060008.

[27] Blattner, F. R., Plunkett, G., 3rd, Bloch, C. A., Perna, N. T., Burland, V., Riley, M., Collado-Vides, J., Glasner, J. D., Rode, C. K., Mayhew, G. F., Gregor, J., Davis, N. W., Kirkpatrick, H. A., Goeden, M. A., Rose, D. J., Mau, B., and Shao, Y. (1997) The complete genome sequence of Escherichia coli K-12, Science 277, 1453-1462.

[28] Temple, C. A., and Rajagopalan, K. V. (2000) Optimization of Expression of Human Sulfite Oxidase and its Molybdenum Domain, Arch. Biochem. Biophys. 383, 281-287.

[29] Ilbert, M., Mejean, V., and Iobbi-Nivol, C. (2004) Functional and structural analysis of members of the TorD family, a large chaperone family dedicated to molybdoproteins, Microbiology 150, 935-943.

[30] Havelius, K. G., Reschke, S., Horn, S., Doring, A., Niks, D., Hille, R., Schulzke, C., Leimkuhler, S., and Haumann, M. (2011) Structure of the molybdenum site in YedY, a sulfite oxidase homologue from Escherichia coli, Inorganic chemistry 50, 741-748. 
[31] Loschi, L., Brokx, S. J., Hills, T. L., Zhang, G., Bertero, M. G., Lovering, A. L., Weiner, J. H., and Strynadka, N. C. (2004) Structural and biochemical identification of a novel bacterial oxidoreductase, J Biol Chem 279, 50391-50400.

[32] Neumann, M., and Leimkühler, S. (2008) Heavy metal ions inhibit molybdoenzyme activity by binding to the dithiolene moiety of molybdopterin in Escherichia coli, The FEBS journal 275, 5678-5689.

[33] Reschke, S., Niks, D., Wilson, H., Sigfridsson, K. G., Haumann, M., Rajagopalan, K. V., Hille, R., and Leimkühler, S. (2013) Effect of exchange of the cysteine molybdenum ligand with selenocysteine on the structure and function of the active site in human sulfite oxidase, Biochemistry 52, 8295-8303.

[34] Johnson, J. L., Hainline, B. E., Rajagopalan, K. V., and Arison, B. H. (1984) The pterin component of the molybdenum cofactor. Structural characterization of two fluorescent derivatives, J. Biol. Chem. 259, 5414-5422.

[35] Reschke, S., Mebs, S., Sigfridsson-Clauss, K. G., Kositzki, R., Leimkühler, S., and Haumann, M. (2017) Protonation and Sulfido versus Oxo Ligation Changes at the Molybdenum Cofactor in Xanthine Dehydrogenase (XDH) Variants Studied by X-ray Absorption Spectroscopy, Inorg Chem 56, 2165-2176.

[36] Schrapers, P., Hartmann, T., Kositzki, R., Dau, H., Reschke, S., Schulzke, C., Leimkuhler, S., and Haumann, M. (2015) Sulfido and cysteine ligation changes at the molybdenum cofactor during substrate conversion by formate dehydrogenase (FDH) from Rhodobacter capsulatus, Inorg Chem 54, 3260-3271.

[37] Dau, H., Liebisch, P., and Haumann, M. (2003) X-ray absorption spectroscopy to analyze nuclear geometry and electronic structure of biological metal centers--potential and questions examined with special focus on the tetra-nuclear manganese complex of oxygenic photosynthesis, Analytical and bioanalytical chemistry 376, 562-583.

[38] Rehr, J. J., Kas, J. J., Vila, F. D., Prange, M. P., and Jorissen, K. (2010) Parameter-free calculations of X-ray spectra with FEFF9, Phys Chem Chem Phys 12, 5503-5513.

[39] Stoll, S., and Schweiger, A. (2006) EasySpin, a comprehensive software package for spectral simulation and analysis in EPR, J. Magn. Reson. 178, 42-55.

[40] Weidinger, A., Waiblinger, M., Pietzak, B., and Almeida Murphy, T. (1998) Atomic nitrogen in C60:N@C60, Applied Physics A 66, 287-292.

[41] Rupp, H., Rao, K. K., Hall, D. O., and Cammack, R. (1978) Electron spin relaxation of iron-sulfur proteins studied by microwave power saturation, In Biochim Biophys Acta, pp 255-269.

[42] Hilton, J. C., Temple, C. A., and Rajagopalan, K. V. (1999) Re-design of Rhodobacter sphaeroides dimethyl sulfoxide reductase. Enhancement of adenosine $\mathrm{N}^{1}$-oxide reductase activity, J. Biol. Chem. 274, 8428-8436.

[43] Raaijmakers, H., Macieira, S., Dias, J. M., Teixeira, S., Bursakov, S., Huber, R., Moura, J. J., Moura, I., and Romao, M. J. (2002) Gene sequence and the 1.8 A crystal structure of the tungsten-containing formate dehydrogenase from Desulfovibrio gigas, Structure $10,1261-1272$.

[44] Wagner, T., Ermler, U., and Shima, S. (2016) The methanogenic CO2 reducing-and-fixing enzyme is bifunctional and contains 46 [4Fe-4S] clusters, Science 354, 114-117.

[45] Hartmann, T., Schrapers, P., Utesch, T., Nimtz, M., Rippers, Y., Dau, H., Mroginski, M. A., Haumann, M., and Leimkuhler, S. (2016) The Molybdenum Active Site of Formate Dehydrogenase Is Capable of Catalyzing $\mathrm{C}-\mathrm{H}$ Bond Cleavage and Oxygen Atom Transfer Reactions, Biochemistry 55, 2381-2389.

[46] Weinert, T., Huwiler, S. G., Kung, J. W., Weidenweber, S., Hellwig, P., Stark, H. J., Biskup, T., Weber, S., Cotelesage, J. J. H., George, G. N., Ermler, U., and Boll, M. 
(2015) Structural basis of enzymatic benzene ring reduction, Nature Chemical Biology $11,586-591$.

[47] Mitra, J., and Sarkar, S. (2013) Modelling the reduced xanthine oxidase in active sulfo and inactive desulfo forms, Dalton Trans 42, 3050-3058.

[48] Mitra, J., and Sarkar, S. (2011) Hydrosulfido molybdenum(V) complexes in relevance to xanthine oxidase, Indian Journal of Chemistry Section a-Inorganic Bio-Inorganic Physical Theoretical \& Analytical Chemistry 50, 401-408.

[49] Bevers, L. E., and Hagen, W. R. (2009) One- and two-electron reduction of molybdate reversibly bound to the archaeal tungstate/molybdate transporter WtpA, Dalton Trans, 8168-8170.

[50] Finnegan, M. G., Hilton, J., Rajagopalan, K. V., and Johnson, M. K. (1993) OpticalTransitions of Molybdenum(V) in Glycerol-Inhibited Dmso Reductase from Rhodobacter-Sphaeroides, Inorganic Chemistry 32, 2616-2617.

[51] Mtei, R. P., Lyashenko, G., Stein, B., Rubie, N., Hille, R., and Kirk, M. L. (2011) Spectroscopic and Electronic Structure Studies of a Dimethyl Sulfoxide Reductase Catalytic Intermediate: Implications for Electron- and Atom-Transfer Reactivity, Journal of the American Chemical Society 133, 9762-9774.

[52] Cammack, R., and Weiner, J. H. (1990) Electron-Paramagnetic Resonance Spectroscopic Characterization of Dimethyl-Sulfoxide Reductase of Escherichia-Coli, Biochemistry 29, 8410-8416.

[53] Mebs, S., Kositzki, R., Duan, J., Kertess, L., Senger, M., Wittkamp, F., Apfel, U. P., Happe, T., Stripp, S. T., Winkler, M., and Haumann, M. (2018) Hydrogen and oxygen trapping at the $\mathrm{H}$-cluster of $[\mathrm{FeFe}]$-hydrogenase revealed by site-selective spectroscopy and QM/MM calculations, Biochim Biophys Acta 1859, 28-41.

[54] Sigfridsson, K. G., Leidel, N., Sanganas, O., Chernev, P., Lenz, O., Yoon, K. S., Nishihara, H., Parkin, A., Armstrong, F. A., Dementin, S., Rousset, M., De Lacey, A. L., and Haumann, M. (2015) Structural differences of oxidized iron-sulfur and nickel-iron cofactors in $\mathrm{O} 2$-tolerant and $\mathrm{O} 2$-sensitive hydrogenases studied by X-ray absorption spectroscopy, Biochim Biophys Acta 1847, 162-170.

[55] Dahl, J. U., Radon, C., Buhning, M., Nimtz, M., Leichert, L. I., Denis, Y., Jourlin-Castelli, C., Iobbi-Nivol, C., Mejean, V., and Leimkuhler, S. (2013) The sulfur carrier protein TusA has a pleiotropic role in Escherichia coli that also affects molybdenum cofactor biosynthesis, J Biol Chem 288, 5426-5442.

[56] Culka, M., Huwiler, S. G., Boll, M., and Ullmann, G. M. (2017) Breaking Benzene Aromaticity-Computational Insights into the Mechanism of the Tungsten-Containing Benzoyl-CoA Reductase, J Am Chem Soc 139, 14488-14500.

[57] Tiedt, O., Fuchs, J., Eisenreich, W., and Boll, M. (2018) A catalytically versatile benzoylCoA reductase, key enzyme in the degradation of methyl- and halobenzoates in denitrifying bacteria, J Biol Chem 293, 10264-10274.

[58] Bray, R. C., Gutteridge, S., Lamy, M. T., and Wilkinson, T. (1983) Equilibria Amongst Different Molybdenum (V)-Containing Species from Sulfite Oxidase - Evidence for a Halide Ligand of Molybdenum in the Low-Ph Species, Biochemical Journal 211, 227 236.

[59] Klein, E. L., Astashkin, A. V., Ganyushin, D., Riplinger, C., Johnson-Winters, K., Neese, F., and Enemark, J. H. (2009) Direct detection and characterization of chloride in the active site of the low-pH form of sulfite oxidase using electron spin echo envelope modulation spectroscopy, isotopic labeling, and density functional theory calculations, Inorg Chem 48, 4743-4752. 
[60] Astashkin, A. V., Klein, E. L., and Enemark, J. H. (2007) Toward modeling the high chloride, low $\mathrm{pH}$ form of sulfite oxidase: K-a-band ESEEM of equatorial chloro ligands in oxomolybdenum(V) complexes, Journal of Inorganic Biochemistry 101, 1623-1629.

[61] Doonan, C. J., Wilson, H. L., Bennett, B., Prince, R. C., Rajagopalan, K. V., and George, G. N. (2008) Mo-V electron paramagnetic resonance of sulfite oxidase revisited: The low-pH chloride signal, Inorganic Chemistry 47, 2033-2038.

[62] Pushie, M. J., Doonan, C. J., Wison, H. L., Rajagopalan, K. V., and George, G. N. (2011) Nature of Halide Binding to the Molybdenum Site of Sulfite Oxidase, Inorganic Chemistry 50, 9406-9413.

[63] Vincent, S. P., and Bray, R. C. (1978) Electron-Paramagnetic-Resonance Studies on Nitrate Reductase from Escherichia-Coli-K12, Biochem. J. 171, 639-647.

[64] Trieber, C. A., Rothery, R. A., and Weiner, J. H. (1996) Consequences of removal of a molybdenum ligand (DmsA-Ser-176) of Escherichia coli dimethyl sulfoxide reductase, J. Biol. Chem. 271, 27339-27345.

[65] Bennett, B., Benson, N., McEwan, A. G., and Bray, R. C. (1994) Multiple states of the molybdenum centre of dimethylsulphoxide reductase from Rhodobacter capsulatus revealed by EPR spectroscopy, European Journal of Biochemistry 225, 321-331.

[66] Rendon, J., Biaso, F., Ceccaldi, P., Toci, R., Seduk, F., Magalon, A., Guigliarelli, B., and Grimaldi, S. (2017) Elucidating the Structures of the Low- and High-pH Mo(V) Species in Respiratory Nitrate Reductase: A Combined EPR, N-14,N-15 HYSCORE, and DFT Study, Inorg. Chem. 56, 4422-4434.

[67] Glasser, N. R., Oyala, P. H., Osborne, T. H., Santini, J. M., and Newman, D. K. (2018) Structural and mechanistic analysis of the arsenate respiratory reductase provides insight into environmental arsenic transformations, Proc. Natl. Acad. Sci., U.S.A. ASAP.

[68] Marques, M. C., Coelho, R., De Lacey, A. L., Pereira, I. A., and Matias, P. M. (2010) The three-dimensional structure of [NiFeSe] hydrogenase from Desulfovibrio vulgaris Hildenborough: a hydrogenase without a bridging ligand in the active site in its oxidised, "as-isolated" state, J Mol Biol 396, 893-907.

[69] Horch, M., Lauterbach, L., Mroginski, M. A., Hildebrandt, P., Lenz, O., and Zebger, I. (2015) Reversible active site sulfoxygenation can explain the oxygen tolerance of a NAD+-reducing $[\mathrm{NiFe}]$ hydrogenase and its unusual infrared spectroscopic properties, J Am Chem Soc 137, 2555-2564.

[70] Grimaldi, S., Biaso, F., Burlat, B., and Guigliareli, B. (2017) Electron Paramagnetic Resonance Studies of Molybdenum Enzymes, Molybdenum and Tungsten Enzymes: Spectroscopic and Theoretical Investigations 7, 68-120.

[71] Wang, H., Chen, X., Li, C., Liu, Y., Yang, F., and Wang, C. (2018) Sequence-Based Prediction of Cysteine Reactivity Using Machine Learning, Biochemistry 57, 451-460. 
For table of contents use only

Identification of YdhV as first molybdoenzyme binding a

bis-Mo-MPT cofactor in Escherichia coli

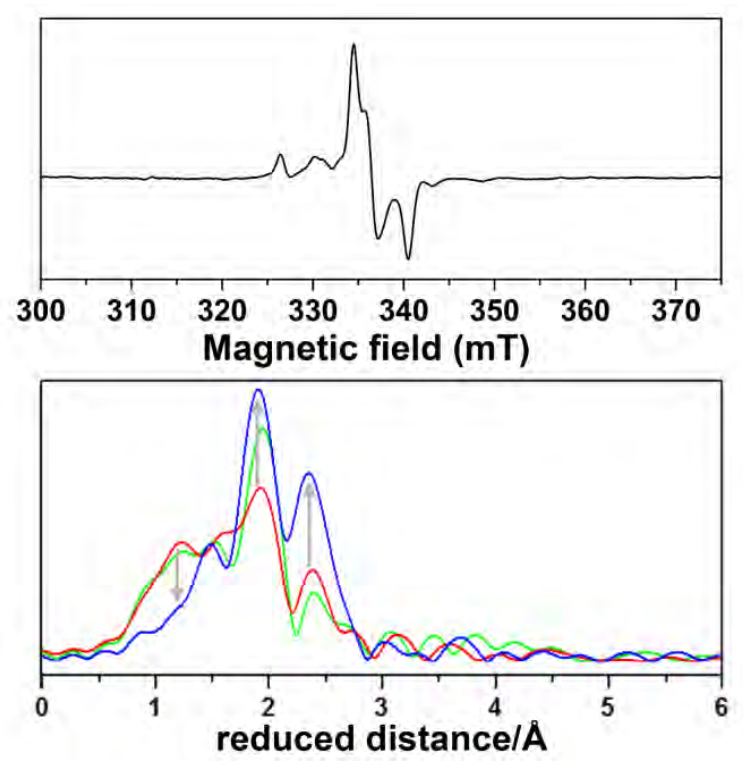

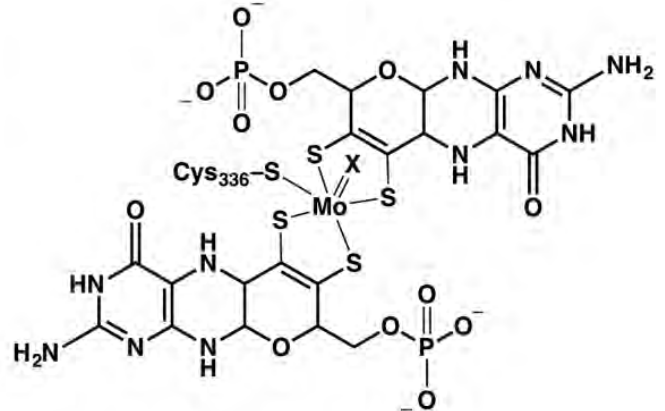

bis-Mo-MPT 


\section{Supporting Information}

\section{Identification of YdhV as first molybdoenzyme binding a bis-Mo-MPT cofactor in Escherichia coli}

Stefan Reschke ${ }^{1 \dagger}$, Benjamin R. Duffus ${ }^{1 \dagger}$, Peer Schrapers ${ }^{2}$, Stefan Mebs ${ }^{2}$, Christian Teutloff ${ }^{3}$, Holger Dau², Michael Haumann ${ }^{2 *}$, Silke Leimkühler ${ }^{2 *}$

${ }^{1}$ Institute of Biochemistry and Biology, University of Potsdam, Karl-Liebknecht-Str. 24, 14476 Potsdam, Germany

${ }^{2}$ Institute of Experimental Physics, Biophysics and Photosynthesis, Freie Universität Berlin, Arnimallee 14, 14195 Berlin, Germany

${ }^{3}$ Institute of Experimental Physics, EPR Spectroscopy of Biological Systems, Freie Universität Berlin, Arnimallee 14, 14195 Berlin, Germany

Author Contributions:

†S.R and B.R.D. contributed equally to this work.

\section{*Corresponding Authors}

${ }^{1}$ Silke Leimkühler, Phone: +49 331977 5603, E-mail: sleim@uni-potsdam.de.

${ }^{2}$ Michael Haumann, Phone: +49 30838 56101, E-mail: michael.haumann@ fu-berlin.de. 


\section{CONTENTS}

Supplementary Tables and Figures

\section{TABLES}

Table S1: YdhV metal quantification and spin concentrations from EPR spectroscopy.

Table S2: Element contents in YdhV from TXRF.

Table S3: W EXAFS simulation parameters.

Table S4: Comparison of spin Hamiltonian parameters for selected molybdoenzymes.

Table S5: Fe EXAFS simulation parameters of YdhV.

\section{FIGURES}

Figure S1: Sequence alignment of YdhV and BamBC (A) and Crystal structure of BamBC (B).

Figure S2: Elemental analysis with TXRF.

Figure S3. X-band EPR spectra of apo-YdhV.

Figure S4. EPR spectral simulation of the Mo(V) signal of ferricyanide-oxidized YdhV at $150 \mathrm{~K}$.

Figure S5. Wide-sweep X-Band EPR spectra of YdhV at low temperature. 
Table S1: YdhV metal quantification and spin concentrations from EPR.

The concentrations of $\mathrm{YdhV}$ were determined by $\mathrm{A}_{280 \mathrm{~nm}}$ absorbance, while the concentrations of Mo, W, and Fe were determined by ICP-OES. The spin concentrations were determined through use of the Matlab toolbox 'spincounting' from the obtained spectra and associated tune picture of the resonator. The reported spin/YdhV relates the amount of spin to YdhV present. Quantitated spin, unless noted otherwise, detected from $80 \mathrm{~K}$ spectra measured with $4 \mathrm{~mW}$ microwave power, $5 \mathrm{G}$ modulation amplitude, and $100 \mathrm{kHz}$ frequency.

\begin{tabular}{|c|c|c|c|c|c|c|}
\hline YdhV; Treatment & $\begin{array}{l}\text { YdhV } \\
(\mu \mathrm{M})\end{array}$ & $\begin{array}{l}\text { Mo } \\
(\mu \mathrm{M})\end{array}$ & $\mathrm{W}(\mu \mathrm{M})$ & $\begin{array}{l}\mathrm{Fe} \\
(\mu \mathrm{M})\end{array}$ & $\begin{array}{l}\text { Spin } \\
(\mu \mathrm{M})\end{array}$ & Spin/YdhV \\
\hline $\begin{array}{l}\text { apo-YdhV } \\
\left(+\mathrm{MoO}_{4}^{2-}\right)^{1,2}\end{array}$ & 1094 & 1328 & N/D & 2100 & & \\
\hline $\begin{array}{l}\text { as-iso } \\
\text { dithionite-reduced } \\
\text { ferrricyanide- } \\
\text { oxidized }\end{array}$ & & & & & $\begin{array}{c}104 \\
147 \\
72\end{array}$ & $\begin{array}{l}0.095 \\
0.134 \\
0.066\end{array}$ \\
\hline $\begin{array}{l}\text { apo-YdhV } \\
\left(-\mathrm{MoO}_{4}^{2-}\right)^{1}\end{array}$ & 662 & 5 & N/D & 927 & & \\
\hline $\begin{array}{l}\text { as-isolated } \\
\text { dithionite-reduced } \\
(12 \mathrm{~K})^{3}\end{array}$ & & & & & $\begin{array}{l}2^{7} \\
60 \\
57\end{array}$ & $\begin{array}{l}0.003 \\
0.091 \\
0.086\end{array}$ \\
\hline $\begin{array}{l}\text { ferrricyanide- } \\
\text { oxidized }\end{array}$ & & & & & $4^{7}$ & 0.006 \\
\hline $\mathrm{YdhV}-\mathrm{Mo}^{2,5}$ & 202 & 380 & $\mathrm{~N} / \mathrm{D}$ & 288 & & \\
\hline $\begin{array}{l}\text { as-isolated } \\
\text { dithionite-reduced } \\
\text { ferrricyanide- } \\
\text { oxidized } \\
(150 \mathrm{~K})^{4}\end{array}$ & & & & & $\begin{array}{c}5 \\
10 \\
17 \\
41\end{array}$ & $\begin{array}{l}0.040 \\
0.080 \\
0.084 \\
0.203\end{array}$ \\
\hline$Y d h V-W^{5,6}$ & 221 & N/D & 977 & N/D & & \\
\hline $\begin{array}{l}\text { as-isolated } \\
\text { dithionite-reduced } \\
\text { ferrricyanide- } \\
\text { oxidized }\end{array}$ & & & & & $\begin{array}{l}17 \\
28 \\
4^{7}\end{array}$ & $\begin{array}{l}0.005 \\
0.126 \\
0.018\end{array}$ \\
\hline
\end{tabular}

N/D not detected.

${ }^{1} \mathrm{YdhV}$ variant was purified and expressed aerobically. The bound Fe-S cluster was highly similar between aerobic and anaerobic expressions and purifications, respectively.

${ }^{2} \mathrm{YdhV}$ was expressed in the presence of $1 \mathrm{mM} \mathrm{MoO}_{4}{ }^{2-}$.

${ }^{3}$ Acquisition parameters at $8 \mu \mathrm{W}$ microwave power, $10 \mathrm{G}$ modulation amplitude, and $100 \mathrm{kHz}$ modulation frequency.

${ }^{4}$ Acquisition parameters at $4 \mathrm{~mW}$ microwave power, $5 \mathrm{G}$ modulation amplitude, and $100 \mathrm{kHz}$ modulation frequency.

${ }^{5} \mathrm{YdhV}$ variant with optimal loading of bis-Mo-MPT, as detected by EPR spectroscopy. YdhV was expressed in the $\triangle m o b A / \triangle m o c A$ deletion strain and was expressed and purified anaerobically.

${ }^{6} \mathrm{YdhV}$ was expressed in the presence of $10 \mu \mathrm{M} \mathrm{WO}_{4}{ }^{2-}$.

${ }^{7}$ It should be noted that the reported quantity of spin is at the limit of detection, therefore representing a negligible spin quantity. 
Table S2: Element contents in YdhV from TXRF. ${ }^{\text {a }}$

\begin{tabular}{c|c|c|c}
\multirow{2}{*}{ preparation } & \multicolumn{3}{|c}{ element per protein } \\
\cline { 2 - 4 } & $\mathrm{P}$ & $\mathrm{Fe}$ & $\mathrm{Br}$ \\
\hline $\mathrm{YdhV}+\mathrm{Cl}$ & $1.7(5)$ & $2.3(9)$ & $0.1(1)$ \\
\hline $\mathrm{YdhV}+\mathrm{Br}$ & $1.5(2)$ & $2.9(5)$ & $0.5(1)$
\end{tabular}

a Data stem from two protein samples for each preparation and 3 repetitions per sample (standard deviation in parenthesis) and were determined relative to a gallium standard added to the protein solutions. $\mathrm{Ni}, \mathrm{Cu}$, and $\mathrm{Zn}$ contents were $\leq 0.4$ metals per protein on average. From a series of YdhV samples to which increasing concentrations of a phosphorus standard were added (Supporting Figure S2), a P per protein ratio of 1.8(2) was determined. 
Table S3: W EXAFS simulation parameters. ${ }^{\mathbf{a}}$

\begin{tabular}{|c|c|c|c|c|c|}
\hline & $\mathrm{W}=\mathrm{O},-\mathrm{OH},-\mathrm{O}$ & $\mathrm{W}=\mathrm{S}$ & W-S & $\mathrm{W}-\mathrm{Cl}^{\mathrm{b}}, \mathrm{W}^{\mathrm{c}}$ & \multirow{2}{*}{$\begin{array}{l}\mathrm{R}_{\mathrm{F}} \\
{[\%]}\end{array}$} \\
\hline & \multicolumn{4}{|c|}{$\mathrm{N}$ [per Mo] / R [̊] / $2 \sigma^{2} \times 10^{3}\left[\AA^{2}\right]$} & \\
\hline YdhV $10 \mu \mathrm{M} \mathrm{W}$ & $\begin{array}{l}0.5^{\#} / 1.72 / 2^{*} \\
0.4^{\#} / 1.81 / 2^{*}\end{array}$ & $0.5^{\#} / 2.24 / 2^{*}$ & $\begin{array}{l}4.0^{*} / 2.40 / 5 \\
0.6^{\#} / 2.53 / 2^{*}\end{array}$ & b $0.1 / 2.79 / 2$ & 19.2 \\
\hline YdhV $1 \mathrm{mM} \mathrm{W}$ & $\begin{array}{c}1.6 / 1.74 / 4^{\S} \\
2.3 / 1.93 / 4^{\S} \\
4.6 / 4.00 / 12^{\$}\end{array}$ & - & - & $\mathrm{c} 4.4 / 3.45 / 12^{\$ *}$ & 21.4 \\
\hline $\mathrm{Na}_{2} \mathrm{WO}_{4} \mathrm{pH} 4.0$ & $\begin{array}{l}2.0 / 1.74 / 8^{\S} \\
1.9 / 1.91 / 8^{\S} \\
6.5 / 3.57 / 2^{\$}\end{array}$ & - & - & ${ }^{\mathrm{c}} 0.8 / 3.51 / 2$ & 28.1 \\
\hline $\mathrm{Na}_{2} \mathrm{WO}_{4} \mathrm{pH} 7.1$ & $\begin{array}{l}3.0 / 1.77 / 5^{\S} \\
1.0 / 2.10 / 5^{\S}\end{array}$ & - & - & - & 23.0 \\
\hline $\mathrm{Na}_{2} \mathrm{WO}_{4} \mathrm{pH} 10.6$ & $3.9 / 1.78 / 2$ & - & - & - & 16.4 \\
\hline
\end{tabular}

${ }^{a} \mathrm{~N}$, coordination number; R, interatomic distance; $2 \sigma^{2}$, Debye-Waller factor; $\mathrm{R}_{\mathrm{F}}$, fit error sum (deviation between Fourier back-transform in a 1.0-3.5 $\AA$ reduced distance window and simulation curve). Fit restraints: *fixed parameter, ${ }^{\#} \mathrm{~N}$-values coupled to yield a sum of $2,{ }^{\S, \$}$ coupled to yield the same value. Parameters correspond to

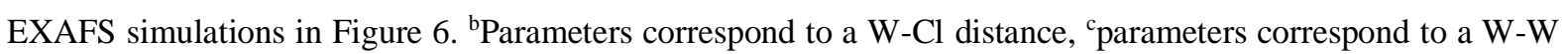
distance. 
Table S4: Comparison of spin Hamiltonian parameters for selected molybdoenzymes. Table denotes signal type for the specified organism and enzyme, and associated $g$-tensor parameters reported, either by simulation or where applicable, by assignment. Where available, the associated ${ }^{95,97}$ Mo hyperfine values, in addition to assigned Euler angles, are provided. Where applicable, associated nuclear quadrupole values and hyperfine values to nuclei other than Mo are excluded.

\begin{tabular}{|c|c|c|c|c|c|c|c|c|}
\hline $\begin{array}{l}\text { Organism, } \\
\text { Enzyme }\end{array}$ & Signal Type & $g$-values & $g_{\mathrm{av}}$ & $g_{1}-g_{3}$ & $\begin{array}{l}\left(g_{1}-g_{2}\right) / \\
\left(g_{1}-g_{3}\right)\end{array}$ & $\begin{array}{c}{ }^{95,97} \mathrm{Mo} \\
\text { Hyperfine (Mo) }\end{array}$ & $\begin{array}{l}\text { Euler } \\
\text { Angles }\end{array}$ & Reference \\
\hline$E c \mathrm{YdhV}$ & $\begin{array}{c}\text { ferricyanide- } \\
\text { oxidized }\end{array}$ & $\begin{array}{l}2.008, \\
1.996, \\
1.973\end{array}$ & 1.992 & 0.035 & 0.350 & $79,149,11$ & $\begin{array}{l}90,104, \\
90\end{array}$ & This work \\
\hline \multirow[t]{3}{*}{$R c$ DMSOR } & $\begin{array}{l}\text { high- } g \text { unsplit } \\
\text { type } 1\end{array}$ & $\begin{array}{l}1.991 \\
1.983 \\
1.961\end{array}$ & 1.978 & 0.030 & 0.250 & N/A & N/A & I \\
\hline & $\begin{array}{l}\text { high- } g \text { unsplit } \\
\text { type } 2\end{array}$ & $\begin{array}{l}1.987 \\
1.983 \\
1.963\end{array}$ & 1.978 & 0.024 & 0.160 & N/A & N/A & 1 \\
\hline & $\begin{array}{l}\text { high- } g \text { unsplit } \\
\text { (glycol) }\end{array}$ & $\begin{array}{l}1.989, \\
1.983, \\
1.964\end{array}$ & 1.979 & 0.025 & 0.243 & N/A & N/A & I \\
\hline \multirow[t]{2}{*}{$R s \mathrm{DMSOR}$} & $\begin{array}{l}\text { high- } g \text { unsplit } \\
\text { (glycerol) }\end{array}$ & $\begin{array}{l}1.99 \\
1.98 \\
1.96\end{array}$ & 1.98 & 0.030 & 0.333 & N/A & N/A & 2 \\
\hline & $\begin{array}{l}\text { high- } g \text { split } \\
\text { (TMAO) }\end{array}$ & $\begin{array}{l}1.999, \\
1.989, \\
1.972\end{array}$ & 1.987 & 0.027 & 0.370 & $40,112,156$ & N/A & 3 \\
\hline$E c$ DMSOR & $\begin{array}{c}\text { poised at } \\
E=-51 \mathrm{mV}\end{array}$ & $\begin{array}{l}1.987 \\
1.976 \\
1.960\end{array}$ & 1.974 & 0.027 & 0.407 & N/A & N/A & $4-6$ \\
\hline \multirow[t]{2}{*}{$E c \mathrm{NarGH}$} & high $\mathrm{pH}$ & $\begin{array}{l}1.987, \\
1.980, \\
1.960\end{array}$ & 1.976 & 0.027 & 0.258 & $97,126,98$ & N/A & $7-9$ \\
\hline & low $\mathrm{pH}$ & $\begin{array}{l}2.001, \\
1.985, \\
1.964\end{array}$ & 1.983 & 0.037 & 0.437 & N/A & N/A & $7-9$ \\
\hline $\begin{array}{l}E c \mathrm{FDH}(\mathrm{Se}) \\
-\mathrm{H}\end{array}$ & $\begin{array}{c}g=2.094 \\
\text { signal }\end{array}$ & $\begin{array}{l}2.094, \\
2.001, \\
1.990\end{array}$ & 2.029 & 0.104 & 0.894 & $118,71,71$ & N/A & 10 \\
\hline$C n$ FFDH & $\begin{array}{l}\text { dithionite- } \\
\text { reduced }\end{array}$ & $\begin{array}{l}2.009, \\
2.001, \\
1.992\end{array}$ & 2.001 & 0.017 & 0.471 & $138,82,45$ & $11,0,153$ & 11 \\
\hline WsPsrABC & $\begin{array}{l}\text { very-high } g \\
\text { (polysulfide) }\end{array}$ & $\begin{array}{l}2.017, \\
2.003, \\
1.987\end{array}$ & 2.002 & 0.029 & 0.481 & $56,56,140$ & N/A & 12 \\
\hline $\begin{array}{l}\text { S.sp. } \\
\text { ArrAB }\end{array}$ & $\begin{array}{l}\text { turnover- } \\
\text { detected }\end{array}$ & $\begin{array}{l}1.990, \\
1.980, \\
1.957\end{array}$ & 1.976 & 0.033 & 0.303 & $122,68,143$ & N/A & 13 \\
\hline $\begin{array}{l}\text { Chicken } \\
\text { SO }\end{array}$ & high $\mathrm{pH}$ & $\begin{array}{l}1.990 \\
1.966, \\
1.954\end{array}$ & 1.970 & 0.036 & 0.666 & $164,63,34$ & $0,14,22$ & 14 \\
\hline PpSoxCD1 & high $\mathrm{pH}$ & $\begin{array}{l}1.985, \\
1.961, \\
1.950\end{array}$ & 1.965 & 0.035 & 0.686 & $162,64,30$ & $0,21,41$ & 15 \\
\hline Bovine XO & very rapid & $\begin{array}{l}2.025, \\
1.955, \\
1.949\end{array}$ & 1.977 & 0.076 & 0.921 & $133,55,57$ & $8,36,0$ & 16 \\
\hline
\end{tabular}




\begin{tabular}{|c|c|c|c|c|c|c|c|c|}
\hline & $\begin{array}{c}\text { rapid type 1 } \\
\text { formamide }\end{array}$ & $\begin{array}{l}1.990, \\
1.971, \\
1.967\end{array}$ & 1.976 & 0.023 & 0.826 & $184,74,77$ & $0,18,0$ & 16 \\
& & & & & & \\
& desulfo & 1.971, & 1.963 & 0.016 & 0.3110 & $196,79,81$ & 81,79, & 17 \\
& & 1.966, \\
1.954 & & & & & 196 & \\
\hline & formaldehyde & 1.991, & 1.973 & 0.040 & 0.349 & $159,69,156$ & 178,69, & 18,19 \\
& -inhibited & 1.977, \\
& 1.951 & & & & & 67 & \\
\hline
\end{tabular}

N/A not applicable

EPR Table References:

[1] Bennett, B., Benson, N., McEwan, A. G., and Bray, R. C. (1994) Multiple states of the molybdenum centre of dimethylsulphoxide reductase from Rhodobacter capsulatus revealed by EPR spectroscopy, Eur. J. Biochem. 225, 321-331.

[2] Finnegan, M. G., Hilton, J., Rajagopalan, K. V., and Johnson, M. K. (1993) Optical-Transitions of Molybdenum(V) in Glycerol-Inhibited Dmso Reductase from R. sphaeroides, Inorg. Chem. 32, 2616-2617.

[3] Mtei, R. P., Lyashenko, G., Stein, B., Rubie, N., Hille, R., and Kirk, M. L. (2011) Spectroscopic and Electronic Structure Studies of a Dimethyl Sulfoxide Reductase Catalytic Intermediate: Implications for Electron- and Atom-Transfer Reactivity, J. Am. Chem. Soc. 133, 9762-9774.

[4] Cammack, R., and Weiner, J. H. (1990) Electron-Paramagnetic Resonance Spectroscopic Characterization of Dimethyl-Sulfoxide Reductase of Escherichia-Coli, Biochemistry 29, 8410-8416.

[5] Trieber, C. A., Rothery, R. A., and Weiner, J. H. (1996) Consequences of removal of a molybdenum ligand (DmsA-Ser-176) of Escherichia coli dimethyl sulfoxide reductase, J. Biol. Chem. 271, 27339-27345.

[6] Rothery, R. A., Trieber, C. A., and Weiner, J. H. (1999) Interactions between the molybdenum cofactor and iron-sulfur clusters of Escherichia coli dimethylsulfoxide reductase, J. Biol. Chem. 274, 13002-13009.

[7] Vincent, S. P., and Bray, R. C. (1978) Electron-Paramagnetic-Resonance Studies on Nitrate Reductase from Escherichia-Coli-K12, Biochem. J. 171, 639-647.

[8] Ceccaldi, P., Rendon, J., Leger, C., Toci, R., Guigliarelli, B., Magalon, A., Grimaldi, S., and Fourmond, V. (2015) Reductive activation of E. coli respiratory nitrate reductase, BBA, Bioenerg. 1847, 1055-1063.

[9] Rendon, J., Biaso, F., Ceccaldi, P., Toci, R., Seduk, F., Magalon, A., Guigliarelli, B., and Grimaldi, S. (2017) Elucidating the Structures of the Low- and High-pH Mo(V) Species in Respiratory Nitrate Reductase: A Combined EPR, N-14,N-15 HYSCORE, and DFT Study, Inorg. Chem. 56, 4422-4434.

[10] Khangulov, S. V., Gladyshev, V. N., Dismukes, G. C., and Stadtman, T. C. (1998) Selenium-containing formate dehydrogenase $\mathrm{H}$ from Escherichia coli: A molybdopterin enzyme that catalyzes formate oxidation without oxygen transfer, Biochemistry 37, 3518-3528.

[11] Niks, D., Duvvuru, J., Escalona, M., and Hille, R. (2016) Spectroscopic and Kinetic Properties of the Molybdenum-containing, $\mathrm{NAD}(+)$ - dependent Formate Dehydrogenase from Ralstonia eutropha, J. Biol. Chem. 291, 1162-1174.

[12] Prisner, T., Lyubenova, S., Atabay, Y., MacMillan, F., Kroger, A., and Klimmek, O. (2003) Multifrequency $\mathrm{cw}$-EPR investigation of the catalytic molybdenum cofactor of polysulfide reductase from Wolinella succinogenes, J. Biol. Inorg. Chem. 8, 419-426.

[13] Glasser, N. R., Oyala, P. H., Osborne, T. H., Santini, J. M., and Newman, D. K. (2018) Structural and mechanistic analysis of the arsenate respiratory reductase provides insight into environmental arsenic transformations, Proc. Natl. Acad. Sci., U.S.A. ASAP.

[14] Dhawan, I. K., and Enemark, J. H. (1996) EPR studies of oxo-molybdenum(V) complexes with sulfur donor ligands: Implications for the molybdenum center of sulfite oxidase, Inorganic Chemistry 35, 4873-4882.

[15] Drew, S. C., Reijerse, E., Quentmeier, A., Rother, D., Friedrich, C. G., and Lubitz, W. (2011) Spectroscopic Characterization of the Molybdenum Cofactor of the Sulfane Dehydrogenase SoxCD from Paracoccus pantotrophus, Inorg. Chem. 50, 409-411.

[16] George, G. N., and Bray, R. C. (1988) Studies by Electron-Paramagnetic Resonance Spectroscopy of Xanthine-Oxidase Enriched with Mo-95 and with Mo-97, Biochemistry 27, 3603-3609.

[17] Wilson, G. L., Greenwood, R. J., Pilbrow, J. R., Spence, J. T., and Wedd, A. G. (1991) Molybdenum(V) Sites in Xanthine-Oxidase and Relevant Analog Complexes - Comparison of Mo-95 and S-33 Hyperfine Coupling, J. Am. Chem. Soc. 113, 6803-6812.

[18] Pick, F. M., McGartoll, M., and Bray, R. C. (1971) Reaction of Formaldehyde and of Methanol with Xanthine Oxidase, Eur. J. Biochem. 18, 65-72.

[19] Sempombe, J., Stein, B., and Kirk, M. L. (2011) Spectroscopic and Electronic Structure Studies Probing Covalency Contributions to C-H Bond Activation and Transition-State Stabilization in Xanthine Oxidase, Inorg. Chem. 50, 10919-10928. 
Table S5: Fe EXAFS simulation parameters of $\mathbf{Y d h V} .^{\mathbf{a}}$

\begin{tabular}{c|c|c} 
Fe-O,C & Fe-S & Fe-Fe \\
\hline \multicolumn{3}{|c}{$\mathrm{N}[$ per Fe] / R $[\AA]$} \\
\hline $1.2 / 2.50$ & $2.1 / 2.23$ & $1.6 / 2.76$ \\
$3.5 / 2.92$ & $1.5 / 2.38$ &
\end{tabular}

aParameters correspond to the EXAFS spectrum in Fig. $9(\mathrm{~N}$, coordination number; $\mathrm{R}$, interatomic distance). The fit error sum, $\mathrm{R}_{\mathrm{F}}$, for reduced distances of $1-3 \AA$ was $10.9 \%$. A Debye-Waller factor $\left(2 \sigma^{2}\right)$ of $0.002 \AA^{2}$ was employed for all shells except the Fe-Fe distance $\left(2 \sigma^{2}=0.005 \AA^{2}\right)$ in the fitting. 


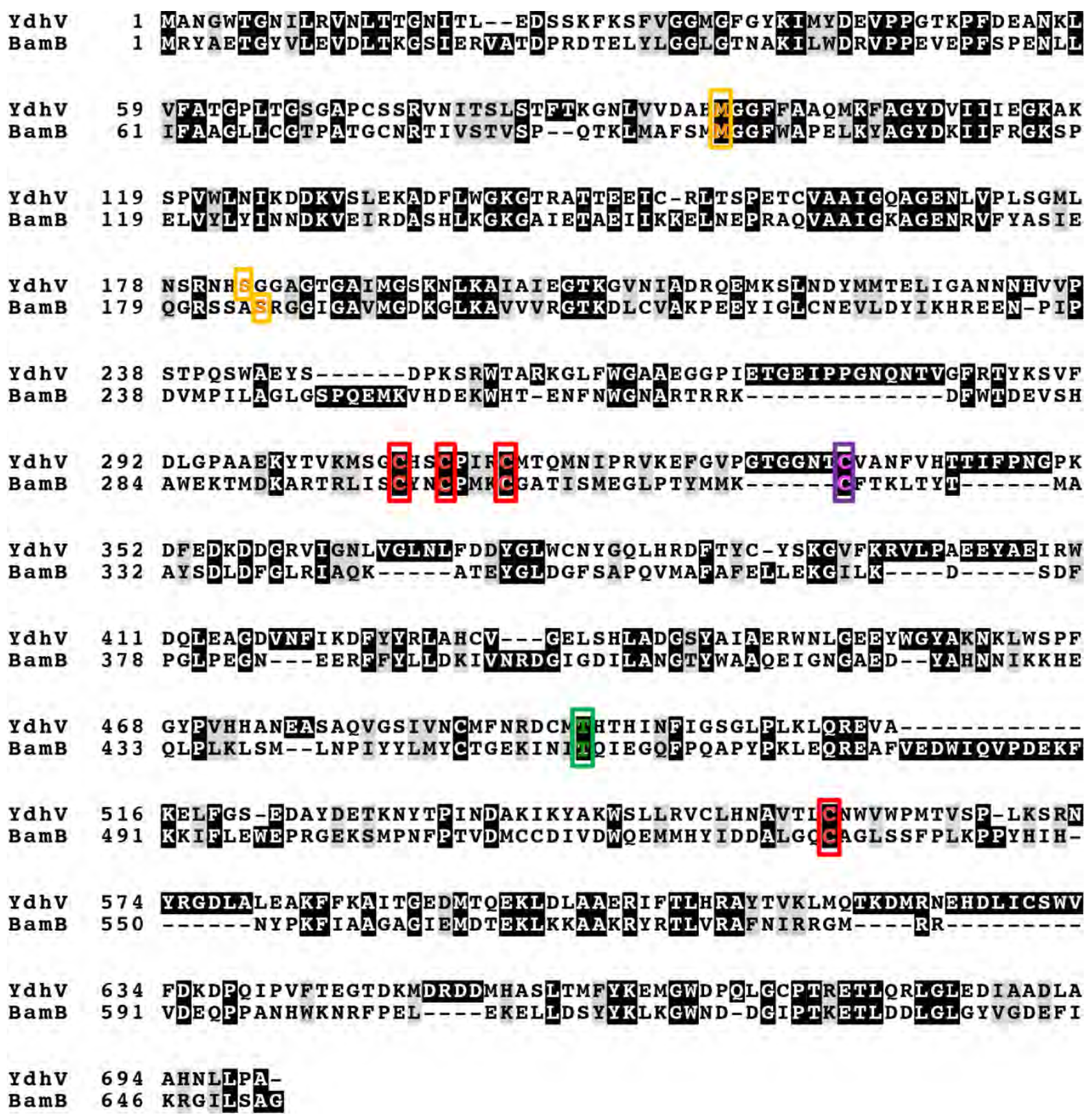

Figure S1A: Sequence alignment of YdhV and BamBC.

Alignment was carried out with Clustal (1.2.4, http://www.uniprot.org/align/) using amino acid sequences for YdhV from E. coli (AKK48365.1) and benzoyl-CoA reductase BamBC (PDB ID 4Z3Y) from Geobacter metallireducens. Colors denote: magenta = Cys322 (C) ligand of $\mathrm{W}$ in BamBC, green $=\mathrm{Thr}$ close to $\mathrm{W}$ in BamBC, red = cysteine $(\mathrm{C})$ ligands to the $[4 \mathrm{Fe}-4 \mathrm{~S}]$ cluster next to the $\mathrm{W}$-cofactor in $\mathrm{BamBC}$, orange = amino acid ligands at the magnesium ion bridging the two MPT units of the W-cofactor in BamBC. 

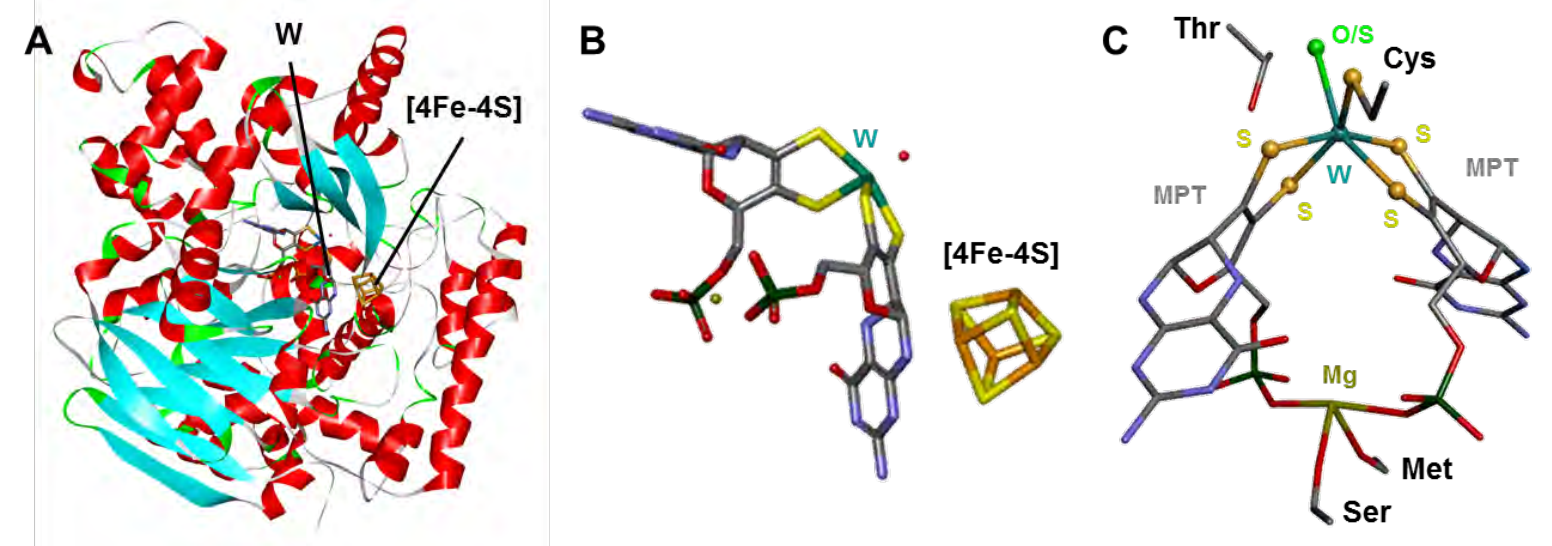

Figure S1B: Crystal structure of BamBC.

(A) Structure (truncated) according to PDB entry 4Z3Y (2.36 Å resolution) with positions of $\mathrm{W}$-cofactor and [4Fe-4S] cluster marked. (B) W-bis-MPT-Mg cofactor with neighboring [4Fe4S] cluster at $\sim 9 \AA$ distance. (C) W-cofactor with bound or neighboring amino acids marked (an $\mathrm{O}$ atom at $\mathrm{W}$ was assigned in the crystal structure). 


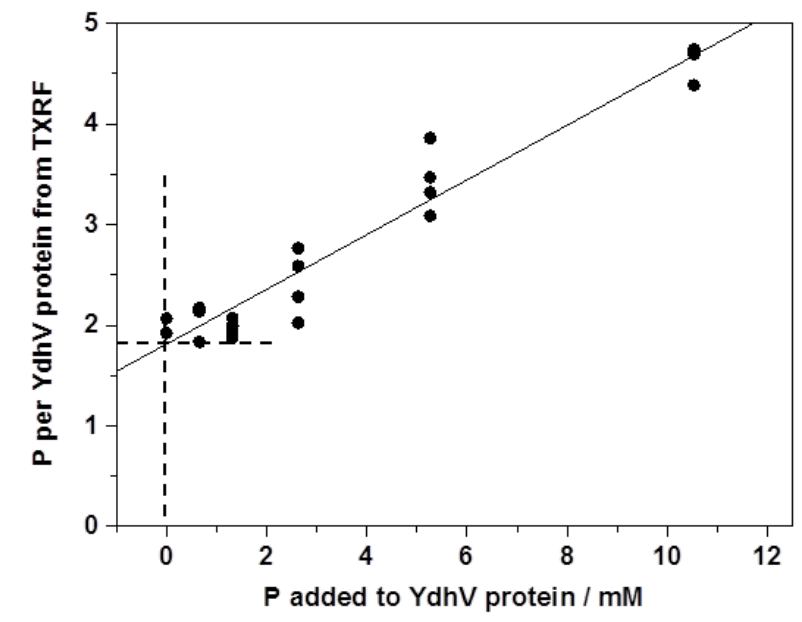

A

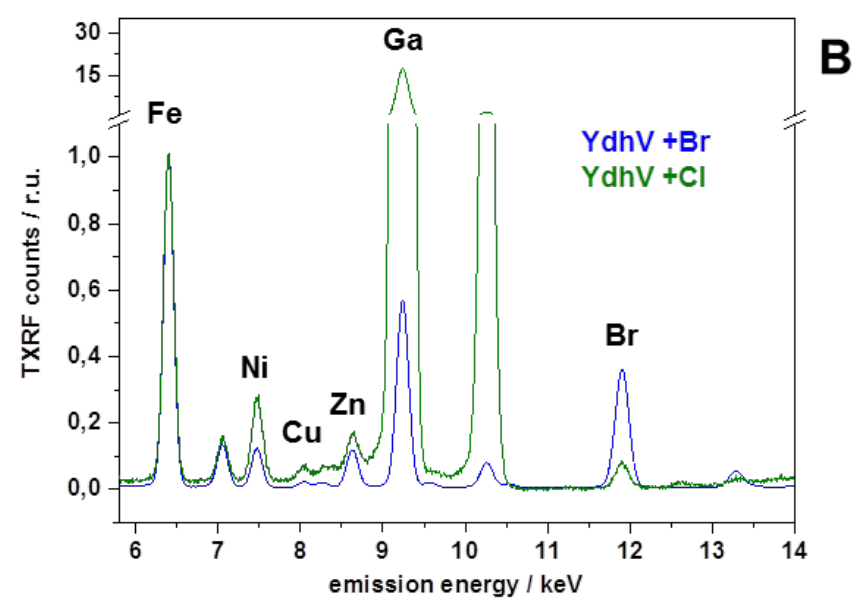

Figure S2: Elemental analysis with TXRF. (A) Phosphorus determination in YdhV protein. To YdhV samples $\left(1.0 \pm 0.1 \mathrm{mM}\right.$ protein), a phosphorus standard $\left(\mathrm{Na}_{3} \mathrm{PO}_{4}\right)$ was added at increasing concentrations (in addition to a gallium concentration standard), the $\mathrm{P}$ contents were determined from TXRF spectra ( $\mathrm{P} \mathrm{K} \alpha$ emission at $~ 2.0 \mathrm{keV}$, not shown), and $\mathrm{P}$ per protein ratios were determined. A linear fit (i.e. extrapolation to zero added $\mathrm{P}$ ) provided a $\mathrm{P}$ per protein content in $\mathrm{YdhV}$ of $1.8 \pm 2$. (B) Quantification of bromine in YdhV samples (green line, $\mathrm{YdhV}$ prepared with $\mathrm{Cl}^{-}$; blue line, $\mathrm{YdhV}$ prepared with $\mathrm{Br}^{-}$; spectra are normalized at the $\mathrm{Fe} \mathrm{K} \alpha$ emission). $\mathrm{K} \alpha$ emission lines of selected elements are marked (unmarked features $=\mathrm{K} \beta$ emission lines). A Ga standard was added to the samples at different concentrations. Element per protein ratios from the TXRF analysis are summarized in Table S2. 


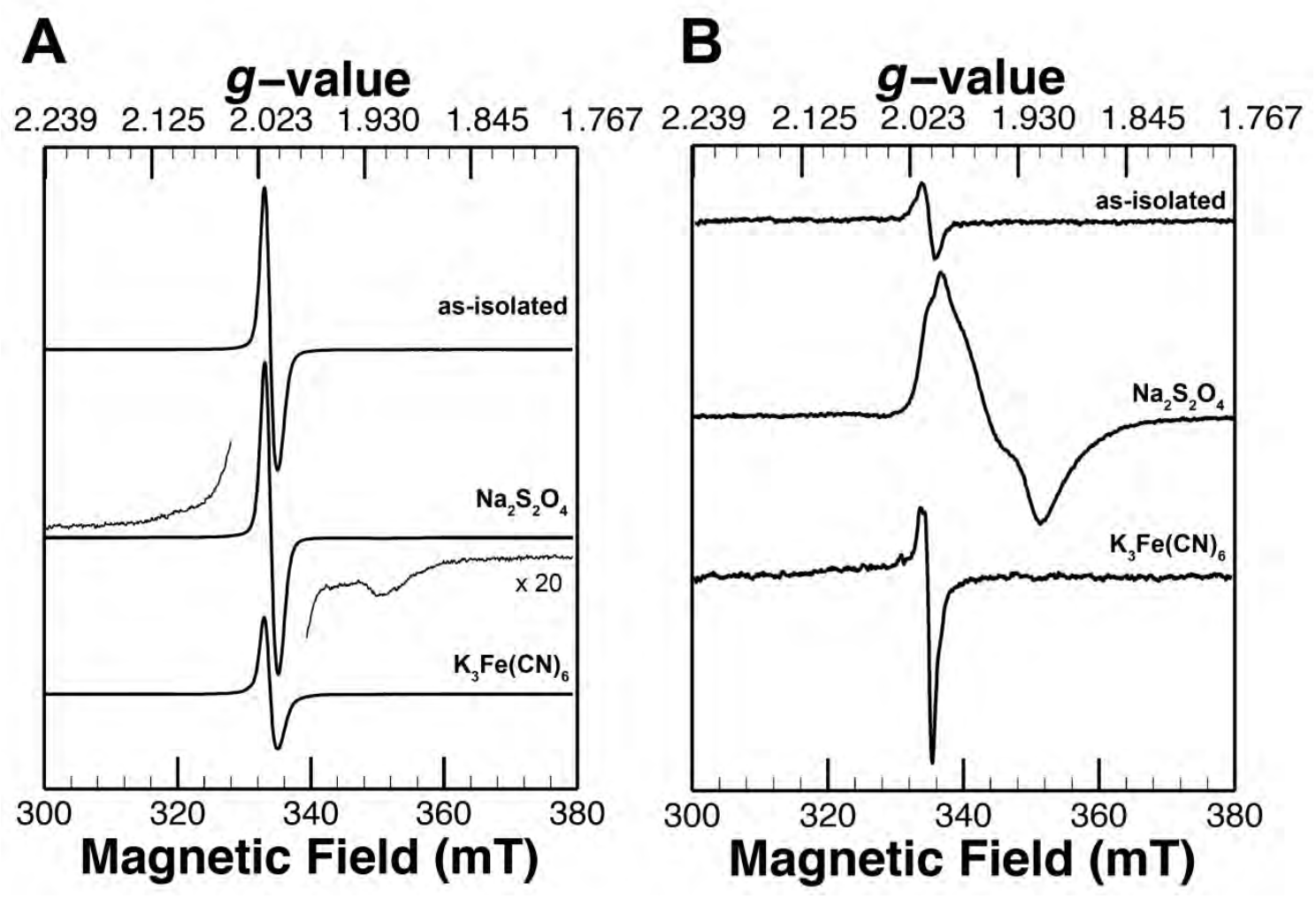

Figure S3: X-band EPR spectra of apo-YdhV. (A) apo-YdhV aerobically expressed in the presence of $1 \mathrm{mM} \mathrm{Na}_{2} \mathrm{MoO}_{4}$, (B) apo-YdhV aerobically expressed without $\mathrm{Na}_{2} \mathrm{MoO}_{4}$. For each panel, the top spectrum represents the as-isolated protein, the middle spectrum represents sodium dithionite-reduced protein, and the bottom spectrum represents $\mathrm{K}_{3} \mathrm{Fe}(\mathrm{CN})_{6}$-oxidized protein. Features present in the baseline are enlarged as noted (thin lines). Spectra were recorded at $80 \mathrm{~K}$ at $4 \mathrm{~mW}$ microwave power, $5 \mathrm{G}$ modulation amplitude and $100 \mathrm{kHz}$ modulation frequency. Spectra have been scaled to represent a YdhV concentration of 1094 $\mu \mathrm{M}$. For associated concentrations of Mo and Fe, see Table S1. 


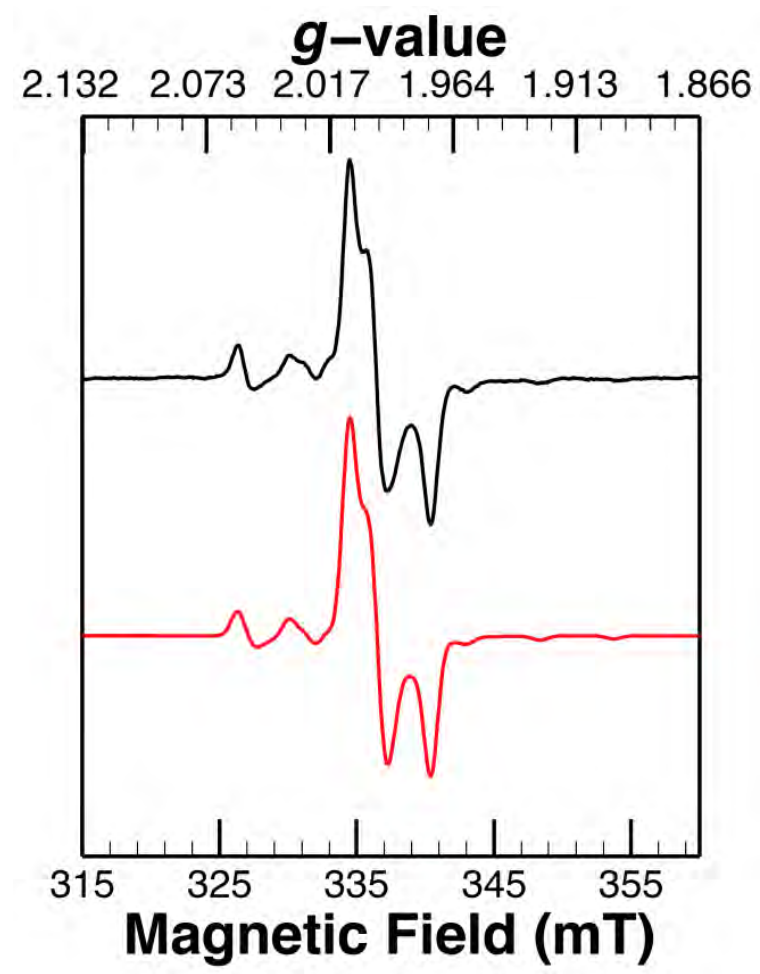

Figure S4: EPR spectral simulation of the Mo(V) signal of ferricyanide-oxidized YdhV at $150 \mathrm{~K}$.

The experimental spectrum (black line) represents ferricyanide-oxidized $\mathrm{YdhV}$ as depicted in Figure 7 (panel A, bottom black spectrum), measured at $150 \mathrm{~K}$ at $4 \mathrm{~mW}$ microwave power, 5 G modulation amplitude and $100 \mathrm{kHz}$ modulation frequency. The spectral simulation (red line) includes two components whereby the Mo isotopes that possess a nuclear spin were treated separately using the simulation toolbox EasySpin. Simulation parameters: $g$ : 2.008, 1.996, $1.973\left(g_{\mathrm{av}}=1.992\right.$, anisotropy $=0.0354$, rhombicity $\left.=0.3503\right), g$-strain: 6.7, 8.2, $6.7\left(\times 10^{-3}\right)$, A: $\left({ }^{95,97} \mathrm{Mo}\right)[78.8,148.7,11.4] \mathrm{MHz}$, Euler angles: 89.8, 103.5, 89.9 (degrees). 

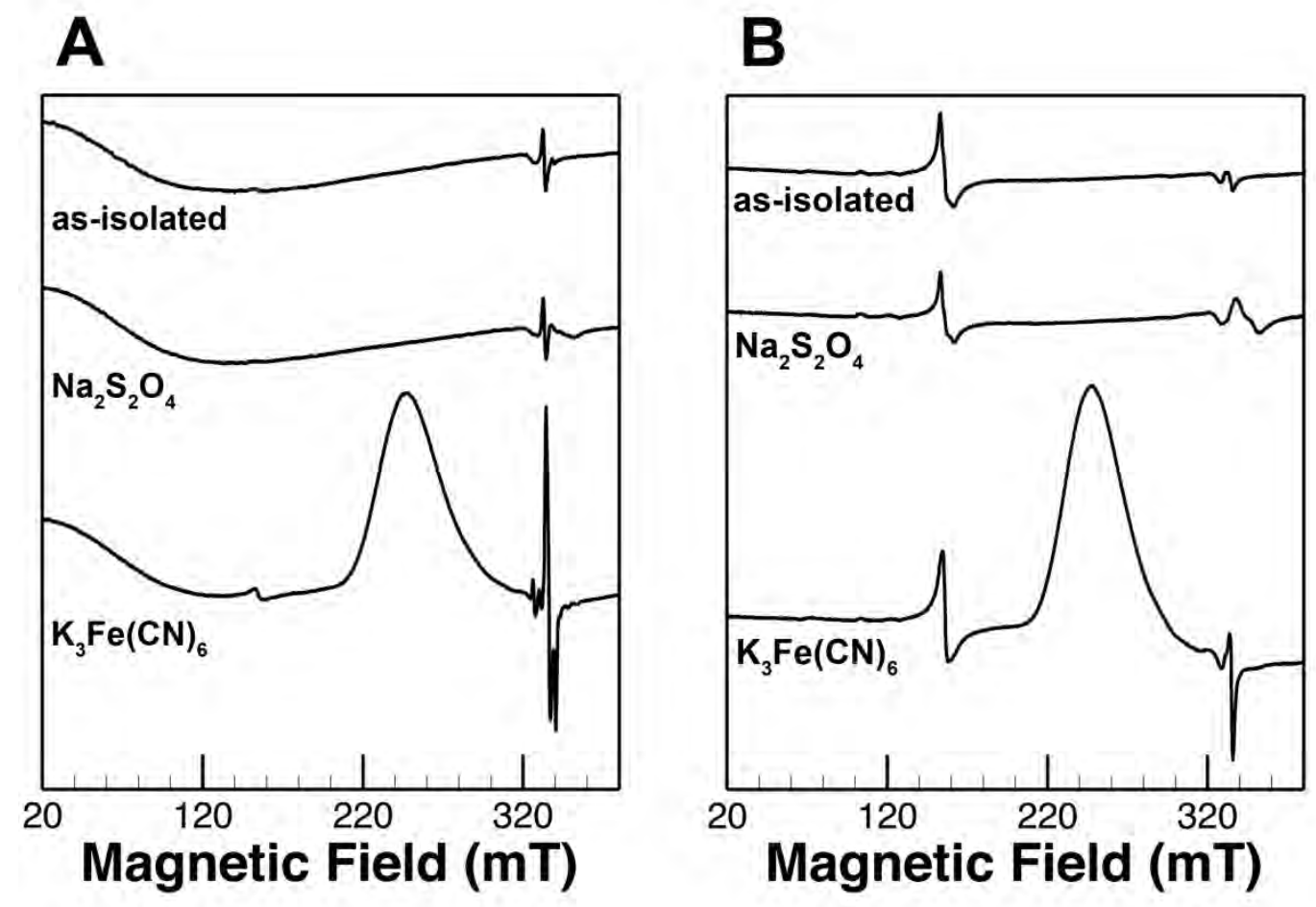

Figure S5: Wide-sweep X-band EPR spectra of YdhV at low temperature.

(A) bis-Mo-MPT-loaded YdhV, (B) apo-YdhV aerobically expressed without $\mathrm{Na}_{2} \mathrm{MoO}_{4}$. Spectra refer to YdhV as-isolated (top), after treatment with $10 \mathrm{mM}$ sodium dithionite (middle), and after treatment with $\mathrm{K}_{3} \mathrm{Fe}(\mathrm{CN})_{6}$ (bottom), and correspond to the spectra of samples in Figure 1 (panel A) and Figure S1 (panel B). Spectra were recorded at $12 \mathrm{~K}$ at $4 \mathrm{~mW}$ microwave power, $5 \mathrm{G}$ modulation amplitude and $100 \mathrm{kHz}$ modulation frequency. Spectra in panel A represent a YdhV concentration of $202 \mu \mathrm{M}$, while spectra in panel B represent a $\mathrm{YdhV}$ concentration of $662 \mu \mathrm{M}$. The large feature at $250 \mathrm{mT}$ in panel A represents the signal of excess paramagnetic ferricyanide in the samples that is readily observed at $12 \mathrm{~K}$. For associated concentrations of Mo and Fe, see Table S1. 